\title{
Preparation and Reactions of Optically Active Cyanohydrins Derived from 4- Chlorobenzaldehyde, Cyclohexanone and 2- Methylcyclohexanone using the $(R)$ Hydroxynitrile lyase from Prunus amygdalus
}

\author{
H. A. A. Yosef, A. M. Elmasry ${ }^{*}$, Eman H.I. Ismael and M. \\ R. H. Mahran \\ Department of Organometallic and Organometalloid \\ Chemistry, National Research Centre, Giza 11211 and \\ *Department of Chemistry, Zagazig University, Zagazig, Egypt.
}

\begin{abstract}
CYANURATION of 4-chlorobenzaldehyde (1), cyclohexanone (2a) and 2-methylcyclo- hexanone (2b) yielded the racemic 2hydroxy-2-(4-chlorophenyl)ethanenitrile $\quad(R, S)-3, \quad$ cyclohexanone cyanohydrin 21a and $(R, S)$-2-methylcyclohexanone cyanohydrin $(R, S)-21 \mathrm{~b}$. The same reaction can be completed by using acetone cyanohydrin (4) as a transcyanating agent. The optically active cyanohydrins $(R)-3$ and $(R)-21$ b could be respectively obtained by hydrocyanation of 1 and $2 \mathrm{~b}$ using $(R)$-hydroxynitrile lyase $(R)$ PaHNL [EC 4.1.2.10] from almonds (Prunus amygdalus) as a chiral catalyst. Cyanohydrins 3 and 21 in their racemic and optically active forms undergo a number of transformations which involve either the hydroxyl group or the cyanide function. Moreover, derivatization of 3 and 21b with $(S)$-Naproxen chloride $(S)-7$ gave the respective diastereoisomers 8 and $22 \mathrm{~b}$. The optical activities of $(R)-3$ and $21 \mathrm{~b}$ as well as their derivatives were recorded. The postulated structures of the new products were supported with compatible elementary and spectroscopic (IR, ${ }^{1} \mathrm{H} \quad \mathrm{NMR},{ }^{13} \mathrm{C} \quad \mathrm{NMR}, \quad \mathrm{MS}$ and $\mathrm{X}$-ray crystallography) analyses. The antitumor activity of some selected racemic new products and their respective optically active analogues were undertaken. The structure-activity relationship (SAR) was also discussed.
\end{abstract}

Keywords: Antitumor activity, Carbonyl compounds, Cyanohydrins, Enzymes and Stereochemistry.

Cyanohydrins are valuable key building blocks and expedient synthones for the one step synthesis of several classes of compounds such as $\alpha$ hydroxycarboxylic acids ${ }^{(1-6)}$ which display a vital role in organic syntheses ${ }^{(7-9)}$. Optically active cyanohydrins are also remarkable intermediates in organic synthesis and have received considerable amount of interest particularly in the last three decades ${ }^{(1-3,10-12)}$. A number of methods for the preparation of optically pure cyanohydrins have been developed using various chiral catalysts ${ }^{(13,14)}$ such as cyclic dipeptides $^{(15,16)}$ as well as chiral complexes of titanium ${ }^{(17)}$, aluminum ${ }^{(18)}$ 
and boron ${ }^{(19)}$.The enantioselective preparation of cyanohydrins has also been performed enzymatically by means of hydroxynitrile lyases (oxynitrilases) from different plant sources ${ }^{(3,20)}$. This approach is rather precise, clean and cheap. It entails a high degree of stereoselectivity leading to optically pure chiral cyanohydrins $^{(1,21-24)}$. The preparation of racemic and optically active cyanohydrins derived from 4-chlorobenzaldehyde (1), cyclohexanone (2a) and 2-methylcyclohxan- one (2b) is the theme of the present study.<smiles>O=Cc1ccc(Cl)cc1</smiles>

1<smiles>[R]C1CCCCC1=O</smiles>

2a, $\mathrm{R}=\mathrm{H}$

b, $\mathrm{R}=\mathrm{CH}_{3}$

A comparative study on the antitumor activity of some newly prepared racemic products and their optically active analogues is also endeavored. This might be of a particular significance due to the well established correlation between the biological activity and stereochemical aspects ${ }^{(6,25)}$.

\section{Results and Discussion}

Hydrocyanation of 4-chlorobenzaldehyde (1)

It has been now found that treatment of aldehyde 1 with aqueous potassium cyanide in presence of $30 \%$ aqueous sulphuric acid yields 2-hydroxyl-2-(4chlorophenyl)ethane- nitrile $(R, S) 3$ in an $87 \%$ yield. Formation of 3 can also be completed by using acetone cyanohydrin (4) as a transcyanating agent ${ }^{(26)}$ (Scheme1).

The IR spectrum of $(R, S) 3\left(\mathrm{KBr}, \mathrm{cm}^{-1}\right)$ showed strong absorption bands at $3390(\mathrm{O}-\mathrm{H}), 2254(\mathrm{C} \equiv \mathrm{N})$ and at $1595\left(\mathrm{C}=\mathrm{C}\right.$ aromatic). Its ${ }^{1} \mathrm{H}$ NMR spectrum $\left(\mathrm{CDCl}_{3}, \delta \mathrm{ppm}\right)$ showed signals at $4.69\left(\mathrm{OH}, \mathrm{D}_{2} \mathrm{O}\right.$ exchangeable, bs $)$ and at 5.48 $(1 \mathrm{H}, H \mathrm{C}-\mathrm{CN}, \mathrm{s})$. The $\mathrm{AB}$ system due to the aromatic protons $(4 \mathrm{H})$ appeared as two doublets (each with $\mathrm{J}_{\mathrm{HH}}=8.4 \mathrm{~Hz}$ ) at $\delta=7.29 \mathrm{ppm}$ and $\delta=7.33 \mathrm{ppm}$. Similarly, $(R)$-2- hydroxyl-2-(4-chlorophenyl)ethane- nitrile $(R)-3$ could be obtained by cyanohydration of 1 directly using $(R)$-oxynitrilase [EC 4.1.2.10]

Egypt. J. Chem. 53, No. 5 (2010) 
from almonds which is a rich source of this enzyme, ${ }^{(27)}$ or by using acetone cyanohydrin (4) as a transcyanating agent in the presence of powdered defatted almond meal as a catalyst. This meal provides an inexpensive catalyst; the use of which eliminates the need to purify and immobilize the enzyme ${ }^{(26)}$. Compound $(R)-3$ was isolated as a yellow oil with $[\alpha]_{\mathrm{D} / 25}=+178$ and in an $98 \%$ yield. The $(R)$ assignments for 3 and its derivatives are based on the Cahn-Ingold-Prelog (CIP) priority rule ${ }^{(28)}$. Both of racemic $(R, S)-3$ and optically active $(R)-3$ forms of the cyanohydrin 3 undergo a number of transformations which involve either the hydroxyl group or the cyano-function in their molecules (Scheme 2).

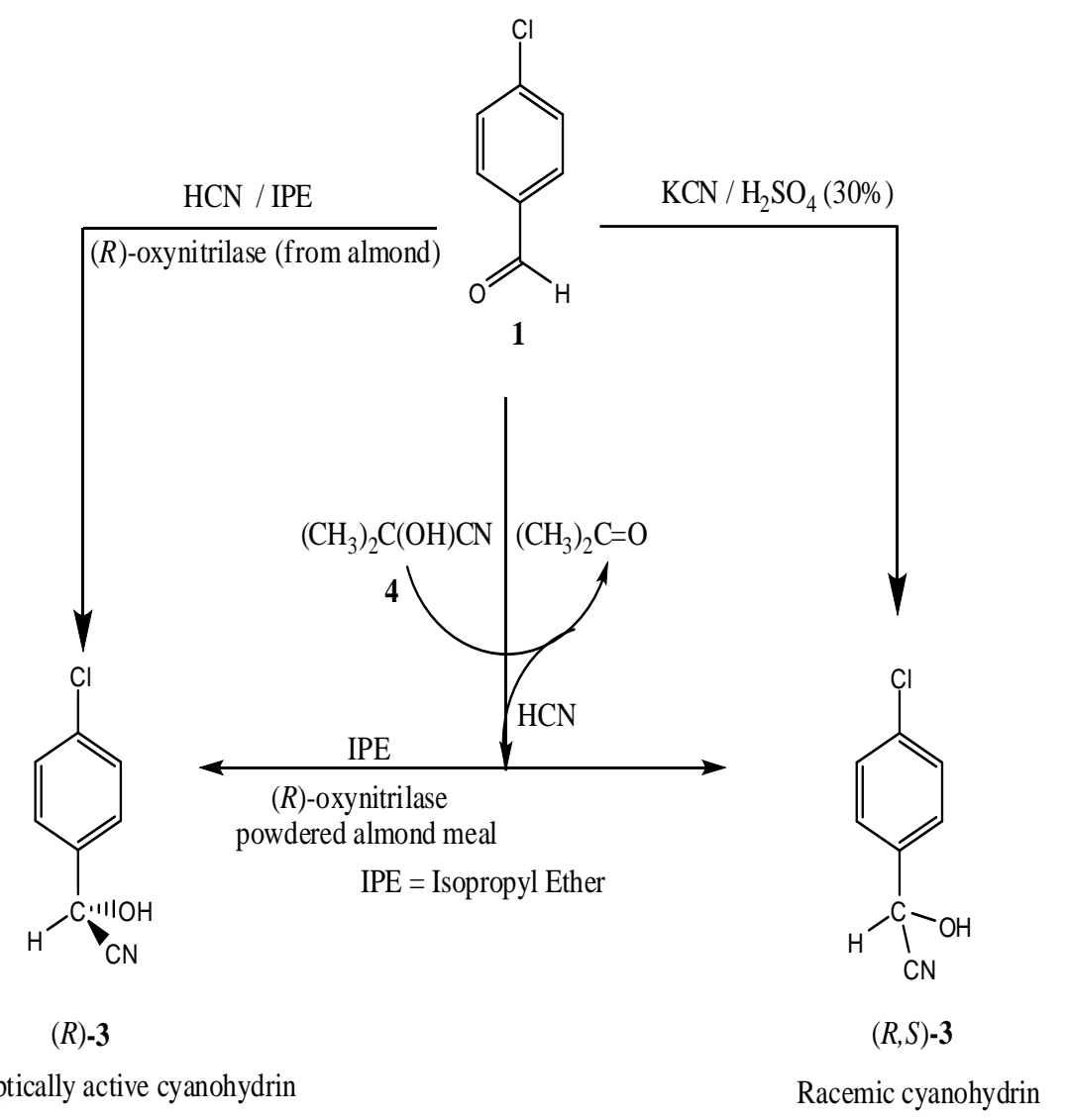

Scheme 1

Egypt. J. Chem. 53, No. 5 (2010) 


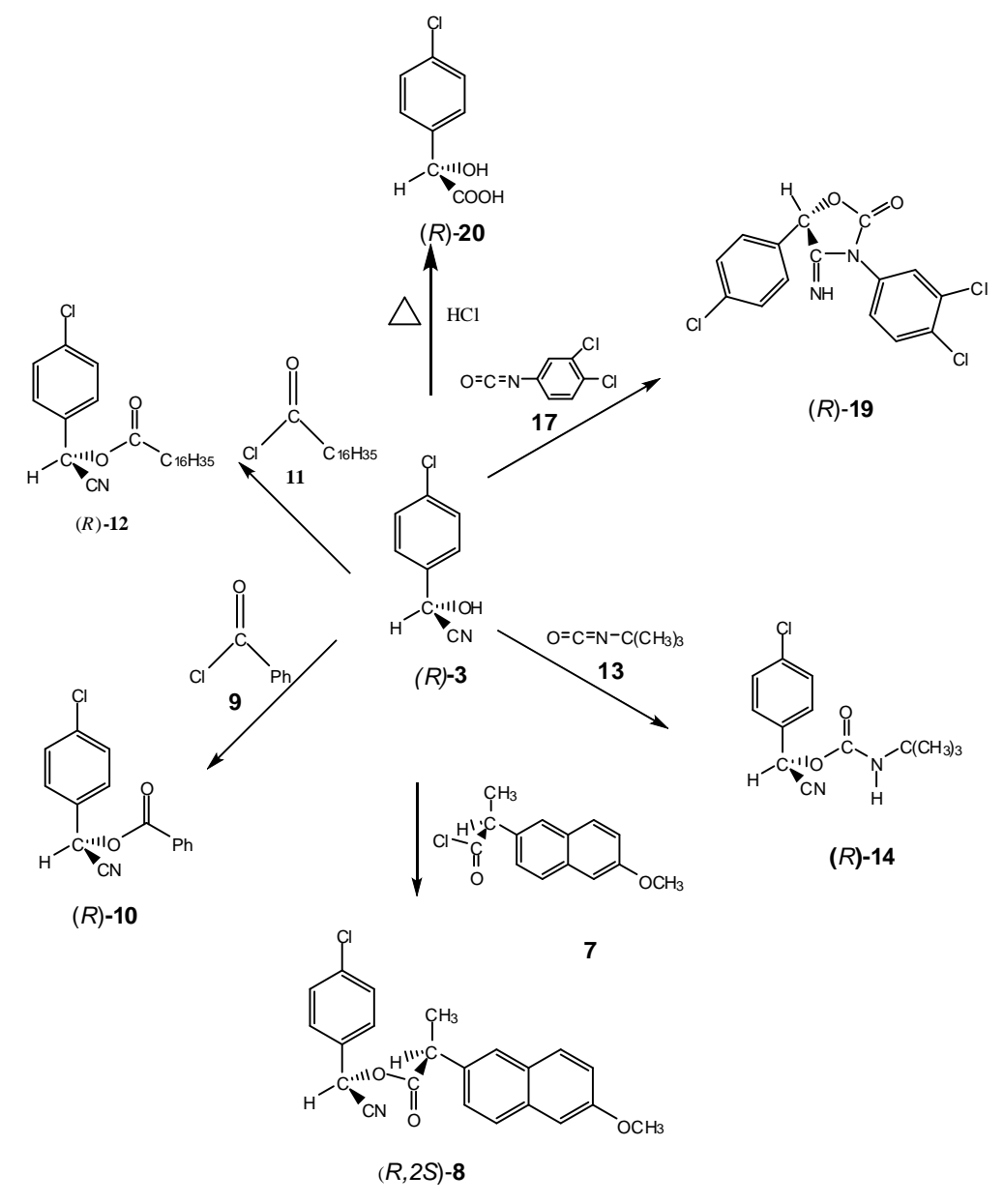

Scheme 2

Reactions of the hydroxyl group

The use of $(S)$-naproxen ${ }^{\circledR}(5)$ as a derivatizing agent to determine the optical purity of organic compounds ${ }^{(29)}$ and as a chiral resolving agent for converting racemates to a mixtue of diastereoisomers ${ }^{(30,31)}$ is very well known. Thus, it has been now found that derivatization of $(R)$-3 with $(S)$-naproxen chloride $(S)$-7 proceeds in $\mathrm{CH}_{2} \mathrm{Cl}_{2}$ in the presence of pyridine to give the respective diastereoisomer namely $(2 S)-((R)-(-)-(4-c h l o r o-$ phenyl))cyano) methyl)-2-(6methoxynaphthalene-2-yl)propanoat $(R, 2 S)-8$ with a diastreomeric excess value (de) of $95 \%$ which reflects the enantiomeric excess and/or the optical purity of the starting cyanohydrin $(R)-3$. Naproxen ${ }^{\circledR}(5)$ could be obtained by extraction

Egypt. J. Chem. 53, No. 5 (2010) 
from commercially available tablets ${ }^{(29)}$ with chloroform. Treatment of (5) with oxalyl chloride (6) in hexane yields the acid chloride $7^{(29)}$ (Scheme 3).<smiles>COc1ccc2cc(C(C)(C)C(=O)OCC(=O)OC(C)(c3ccc(Cl)cc3)c3ccc4cc(OC)ccc4c3)ccc2c1</smiles>

\section{Scheme 3}

Elementary and molecular weight determination (MS) for $(R, 2 S)-8$ corresponded to $\mathrm{C}_{22} \mathrm{H}_{18} \mathrm{ClNO}_{3}$. Structural reasoning for $(R, 2 S)-8$ are:

(i) Its IR spectrum $\left(\mathrm{KBr}, \mathrm{cm}^{-1}\right)$ disclosed the presence of strong absorption bands at $2935(\mathrm{CH}$, aliphatic), $2238(\mathrm{C} \equiv \mathrm{N}), 1744(\mathrm{C}=\mathrm{O}$, ester), 1624, 1604 $(\mathrm{C}=\mathrm{C}$, aromatic) and at 1247 (C-O, stretching).

(ii) Its ${ }^{1} \mathrm{H}$ NMR spectrum (DMSO- $\left.\mathrm{d}_{6}, \delta \mathrm{ppm}\right)$ showed signals at $1.48(3 \mathrm{H}, \mathrm{C}-$ $\left.\mathrm{CH}_{3}, \mathrm{~d}, \mathrm{~J}_{\mathrm{HH}}=7.6 \mathrm{~Hz}\right), 3.83\left(3 \mathrm{H}, \mathrm{OCH}_{3}, \mathrm{~s}\right), 4.08\left(1 \mathrm{H}, \mathrm{C}-\mathrm{CH}, \mathrm{q}, \mathrm{J}_{\mathrm{HH}}=7.6 \mathrm{~Hz}\right)$ and $7.26(10 \mathrm{H}$, aromatics) as a multiplet wherein emerge two doublets (each with $\mathrm{J}_{\mathrm{HH}}=8.4 \mathrm{~Hz}$ ) due to protons of the 4-chlorophenyl moiety $(4 \mathrm{H})$ at $\delta=7.32$ and $7.39 \mathrm{ppm}$.

(iii) The mass spectrum of $(R, 2 S)-8$ showed the molecular ion peak at $\mathrm{m} / \mathrm{z}$ $379\left(60 \%\right.$, based on $\left.{ }^{35} \mathrm{Cl}\right)$ and $\mathrm{m} / \mathrm{z} 381\left(20 \%\right.$ based on ${ }^{37} \mathrm{Cl}$.).

Derivatization of the hydroxyl groups through their reactions with acid chlorides gives the corresponding esters. Such protection of the hydroxyl group represents an important reaction in organic syntheses ${ }^{(32)}$ as well as in gas chromatography analysis methods ${ }^{(33)}$. Thus, benzoylation of $(R)-3$ with benzoyl chloride (9) yielded $(R)-(+)$-(4-chlorophenyl)-cyanomethyl benzoate $(R)-10$ (Scheme 2). Similarly, treatment of $(R)-3$ with stearoyl chloride (11) in dry methylene chloride yielded $(R)-(+)-(4-$ chlorophenyl)cyanomethyl stearate $(R)-12$ (Scheme 2). 
Treatment of $(R)-3$ with tert-butylisocyanate (13) in THF in presence of a few drops of triethylamine (TEA) yielded a white crystalline substance formulated as $(R)-(+)$-(4-chlorophenyl)cyanomethyl tert-butylcarbamate $(R)-(+)$ 14 (Scheme 2). An ORTEP overview of compound $(R)-14$ is represented in Fig. 1. The crystal structural data, selected bond lengths as well as bond angels of $(R)-14$ are represented in Tables 1,2 and 3, respectively.

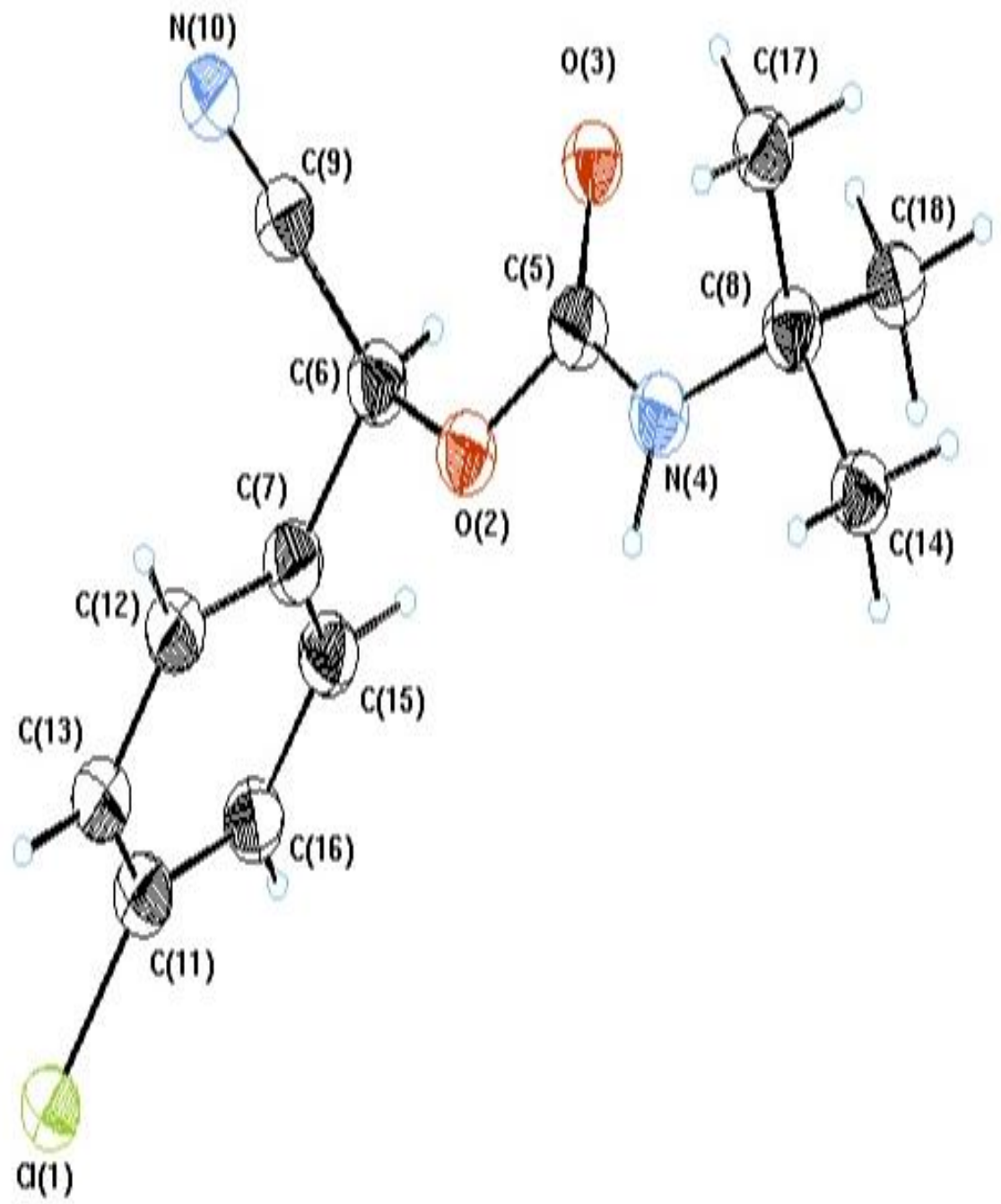

Fig. 1. An ORTEP overview of compound $(R)-14$. 
TABLE 1. Crystal structure and data refinement parameters of compound $(R)-14 *$.

\begin{tabular}{|l|l|}
\hline Compound & $(\boldsymbol{R})-\mathbf{1 4}$ \\
\hline Empirical Formula & $\mathrm{C}_{13} \mathrm{H}_{15} \mathrm{ClN}_{2} \mathrm{O}_{2}$ \\
Formula Weight & 266.728 \\
Crystal System / Space Group & Monoclinic / C2/c \\
$\mathrm{a} / \AA$ & $26.1653(8)$ \\
$\mathrm{b} / \AA$ & $11.3305(4)$ \\
$\mathrm{c} / \AA$ & $9.9275(4)$ \\
$\alpha /{ }^{\circ}$ & 90.00 \\
$\beta / \circ$ & $104.990(2)$ \\
$\gamma /{ }^{\circ}$ & 90.00 \\
$\mathrm{~V} / \AA^{3}$ & $2843.0(2)$ \\
$\mathrm{Z}$ & 8 \\
$\mathrm{D}$ calc $\left(\mathrm{g} / \mathrm{cm}{ }^{3}\right)$ & 1.246 \\
$\mu($ mm & -1 \\
Colour / Shape & 0.26 \\
Theta range for collection & $\mathrm{Colourless/Cube}$ \\
Reflections collected & $2.910-27.485$ \\
Independent reflections & 9858 \\
Data / restraints / parameters & 3622 \\
Goodness of fit on F $\mathrm{F}^{2}$ & $1763 / 0 / 163$ \\
Final R indices [I $>2 \sigma(\mathrm{I})]$ & 1.989 \\
$\mathrm{R}$ indices (all data) & 0.066 \\
& 0.131 \\
Largest difference peak / hole & \\
& \\
\hline
\end{tabular}

*Temperature: 298 K, Wavelength: Mo $K \alpha$ ( $0.71073 \AA$ )

TABLE 2. Selected bond lengths ( $\AA$ ) of compound (R)-14.

\begin{tabular}{|rr|rr|}
\hline $\mathrm{C} 11-\mathrm{C} 11$ & $1.742(3)$ & $\mathrm{C} 7-\mathrm{C} 15$ & $1.366(3)$ \\
$\mathrm{O} 2-\mathrm{C} 5$ & $1.373(2)$ & $\mathrm{C} 8-\mathrm{C} 14$ & $1.510(3)$ \\
$\mathrm{O} 2-\mathrm{C} 6$ & $1.439(2)$ & $\mathrm{C} 8-\mathrm{C} 17$ & $1.479(4)$ \\
$\mathrm{O} 3-\mathrm{C} 5$ & $1.210(2)$ & $\mathrm{C} 8-\mathrm{C} 18$ & $1.534(4)$ \\
$\mathrm{N} 4-\mathrm{C} 5$ & $1.330(3)$ & $\mathrm{C} 9-\mathrm{N} 10$ & $1.135(3)$ \\
$\mathrm{N} 4-\mathrm{C} 8$ & $1.478(3)$ & $\mathrm{C} 11-\mathrm{C} 13$ & $1.369(4)$ \\
$\mathrm{C} 6-\mathrm{C} 7$ & $1.506(3)$ & $\mathrm{C} 11-\mathrm{C} 16$ & $1.373(4)$ \\
$\mathrm{C} 6-\mathrm{C} 9$ & $1.478(3)$ & $\mathrm{C} 12-\mathrm{C} 13$ & $1.381(4)$ \\
$\mathrm{C} 7-\mathrm{C} 12$ & $1.389(3)$ & $\mathrm{C} 15-\mathrm{C} 16$ & $1.380(4)$ \\
\hline
\end{tabular}


TABLE 3. Selected bond angels (degree) of compound (R)-14.

\begin{tabular}{|ll|ll|}
\hline $\mathrm{C} 5-\mathrm{O} 2-\mathrm{C} 6$ & $115.12(14)$ & $\mathrm{N} 4-\mathrm{C} 8-\mathrm{C} 17$ & $111.2(2)$ \\
$\mathrm{C} 5-\mathrm{N} 4-\mathrm{C} 8$ & $125.4(2)$ & $\mathrm{N} 4-\mathrm{C} 8-\mathrm{C} 18$ & $109.4(2)$ \\
$\mathrm{O} 2-\mathrm{C} 5-\mathrm{O} 3$ & $122.0(2)$ & $\mathrm{C} 14-\mathrm{C} 8-\mathrm{C} 17$ & $109.8(2)$ \\
$\mathrm{O} 2-\mathrm{C} 5-\mathrm{N} 4$ & $109.9(2)$ & $\mathrm{C} 14-\mathrm{C} 8-\mathrm{C} 18$ & $106.3(2)$ \\
$\mathrm{O} 3-\mathrm{C} 5-\mathrm{N} 4$ & $128.1(2)$ & $\mathrm{C} 17-\mathrm{C} 8-\mathrm{C} 18$ & $112.9(3)$ \\
$\mathrm{O} 2-\mathrm{C} 6-\mathrm{C} 7$ & $107.3(2)$ & $\mathrm{C} 6-\mathrm{C} 9-\mathrm{N} 10$ & $177.3(2)$ \\
$\mathrm{O} 2-\mathrm{C} 6-\mathrm{C} 9$ & $109.3(2)$ & $\mathrm{C} 11-\mathrm{C} 11-\mathrm{C} 13$ & $119.1(2)$ \\
$\mathrm{C} 7-\mathrm{C} 6-\mathrm{C} 9$ & $112.3(2)$ & $\mathrm{C} 11-\mathrm{C} 11-\mathrm{C} 16$ & $120.0(2)$ \\
$\mathrm{C} 6-\mathrm{C} 7-\mathrm{C} 12$ & $120.7(2)$ & $\mathrm{C} 13-\mathrm{C} 11-\mathrm{C} 16$ & $120.8(3)$ \\
$\mathrm{C} 6-\mathrm{C} 7-\mathrm{C} 15$ & $120.3(2)$ & $\mathrm{C} 7-\mathrm{C} 12-\mathrm{C} 13$ & $120.4(2)$ \\
$\mathrm{C} 12-\mathrm{C} 7-\mathrm{C} 15$ & $118.9(2)$ & $\mathrm{C} 11-\mathrm{C} 13-\mathrm{C} 12$ & $119.4(2)$ \\
$\mathrm{N} 4-\mathrm{C} 8-\mathrm{C} 14$ & $106.9(2)$ & $\mathrm{C} 7-\mathrm{C} 15-\mathrm{C} 16$ & $121.1(2)$ \\
\hline
\end{tabular}

Under similar conditions, the reaction of $(R, S)$-mandelonitrile ${ }^{(34)}(R, S)-15$ with isocyanate 13 yielded $(R, S)$-phenylcyanomethyl tert-butylcarbamate $(R, S)$ 16.
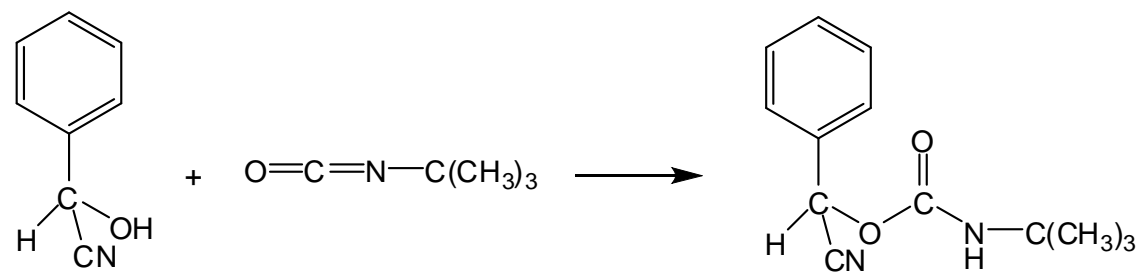

$(R, S)-15$

13

$(R, S)-16$

\section{Scheme 4}

On the other hand, the reaction of $(R)-3$ with 3,4-dichlorophenyl isocyanate 17 yielded a yellow crystalline product formulated as $(5 R)-(+)-3-(3,4-$ dichlorophenyl)-5-(4-chloro- phenyl)-4-iminooxazolidin-2-one $(R)-19$ (Scheme 5). Structural reasonings for $(R)-19$ are :

(i) Compatible elementary and molecular weight determination (MS) corresponded to $\mathrm{C}_{15} \mathrm{H}_{9} \mathrm{Cl}_{3} \mathrm{~N}_{2} \mathrm{O}_{2}$.

(ii) Its IR spectrum $\left(\mathrm{KBr}, \mathrm{cm}^{-1}\right)$ showed strong absorption bands at $3293(\mathrm{~N}-$ $\mathrm{H}), 3095(\mathrm{C}-\mathrm{H}$, aromatic), 1770 ( $\mathrm{C}=\mathrm{O}$, lactone) and at $1594(\mathrm{C}=\mathrm{C}$, aromatic). The spectrum revealed the absence of $(\mathrm{CN})$ group absorption around $2200 \mathrm{~cm}^{-1}$. On the other hand, it showed a strong band at $1683 \mathrm{~cm}^{-1}$ due to the exocyclic $\mathrm{C}=\mathrm{N}$ group absorption.

(iii) The ${ }^{1} \mathrm{H}$ NHR spectrum $\left(\mathrm{CDCl}_{3}, \delta \mathrm{ppm}\right)$ revealed the presence of signals at $5.83 \mathrm{ppm}(1 \mathrm{H}, \mathrm{CH}-\mathrm{O}, \mathrm{s}), 7.35-7.60(7 \mathrm{H}$, aromatic protons a-g) as a multiplet Egypt. J. Chem. 53, No. 5 (2010) 
wherein emerge two doublets (each with $\mathrm{J}_{\mathrm{HH}}=7.65 \mathrm{~Hz}$ ) at 7.42 and $7.47 \mathrm{ppm}$ due to protons a,d and b,c of the 4-chlorophenyl moiety $(4 \mathrm{H})$, respectively.

(iv) The mass spectrum of compound (R)-19 (Scheme 6) showed the molecular ion peak at $\mathrm{m} / \mathrm{z} 354\left(15 \%\right.$ based on $\left.{ }^{35} \mathrm{Cl}\right)$ and $360(<5 \%$ based on $\left.{ }^{37} \mathrm{Cl}\right)$. Loss of carbon dioxide molecule from $\mathrm{M}^{+}$can afford the radical cation a at $\mathrm{m} / \mathrm{z} 310\left(10 \%\right.$ based on $\left.{ }^{35} \mathrm{Cl}\right)$ and $316\left(<3 \%\right.$ based on $\left.{ }^{37} \mathrm{Cl}\right)$. The fragmentation of $\mathrm{M}^{+}$at axis $\mathrm{x}$ with loss of a molecule like $\mathrm{b}$ can give the radical cation $\mathrm{c}$ at $\mathrm{m} / \mathrm{z}$ $140\left(33 \%\right.$ based on $\left.{ }^{35} \mathrm{Cl}\right)$ and at $142\left(10 \%\right.$ based on $\left.{ }^{37} \mathrm{Cl}\right)$. The spectrum also showed ion peaks at $\mathrm{m} / \mathrm{z} 111(68 \%)$ and $113(20 \%)$ for the 4-chloro- phenyl cation d.

Apparently, the reaction of cyanohydrin $(R)-3$ with the isocyanate reagent 17 proceeds to give the respective carbamic acid ester $(R)-18$ which undergoes then an intramolecular rearrangement to yield the final product $(R)-19$ (Scheme 5).<smiles>CC(C)C(OC(=O)Nc1ccc(Cl)c(Cl)c1)c1ccc(Cl)cc1</smiles><smiles>N=C1[C@H](c2ccc(Cl)cc2)OC(=O)N1c1ccc(Cl)c(Cl)c1</smiles>

(R)-19 


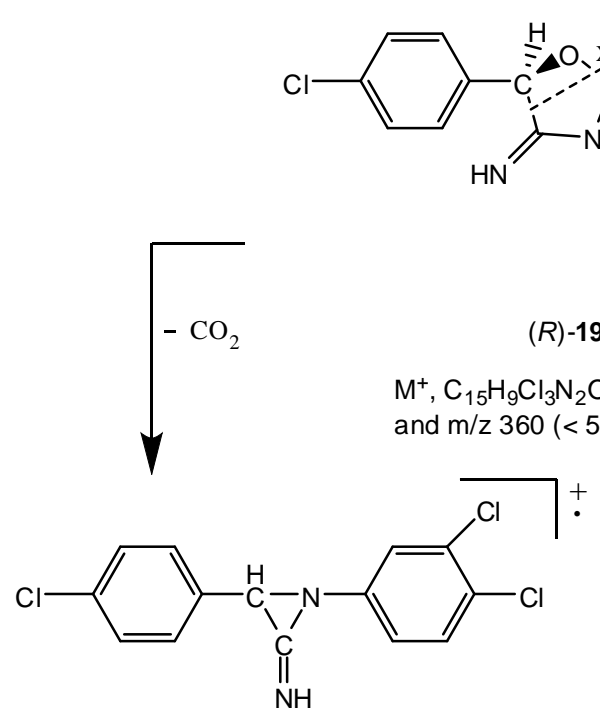

a, $\mathrm{C}_{14} \mathrm{H}_{9} \mathrm{Cl}_{3} \mathrm{~N}_{2}, \mathrm{~m} / \mathrm{z} 310(10 \%)$ and $316(<3 \%)$

c, $\mathrm{C}_{7} \mathrm{H}_{5} \mathrm{ClO}, \mathrm{m} / \mathrm{z} 140(33 \%)$ and $\mathrm{m} / \mathrm{z} 142(10 \%)$<smiles>Clc1ccccc1</smiles>

d, $\mathrm{C}_{6} \mathrm{H}_{4} \mathrm{Cl}, \mathrm{m} / \mathrm{z} 111(68 \%)$ and $\mathrm{m} / \mathrm{z} 113(20 \%)$

\section{Scheme 6}

\section{Reactions of the cyanide function}

Upon heating $(R)-3$ with concentrated hydrochloric acid, it yielded $(R)-(-)-1-$ (4-chloro- phenyl)-1-hydroxyacetic acid (R)-20. Compatible elementary and molecular weight determination (MS) for $(R)-20$ corresponded to $\mathrm{C}_{8} \mathrm{H}_{7} \mathrm{Cl} \mathrm{O}_{3}$.

Structural reasonings for $(R)-20$ are :

a- Its IR spectrum $\left(\mathrm{KBr}, \mathrm{cm}^{-1}\right)$ disclosed the presence of absorption bands at $3374(\mathrm{O}-\mathrm{H}), 1671(\mathrm{C}=\mathrm{O}$, acid), $1591(\mathrm{C}=\mathrm{C}$, aromatic ) and $1284(\mathrm{C}-\mathrm{O}$, stretching ).

b- Its ${ }^{1} \mathrm{H}$ NMR spectrum (DMSO-d 6 , $\delta$ ppm) showed signals at $4.82(1 \mathrm{H}, \mathrm{CH}$ methine, $\mathrm{d}, \mathrm{J}_{\mathrm{HH}}=3.8 \mathrm{~Hz}$; simplified to a singlet upon deuteration, $6.10(1 \mathrm{H}, \mathrm{OH}$, $\mathrm{D}_{2} \mathrm{O}$ exchangeable) and $7.42\left(1 \mathrm{H}, \mathrm{OH}, \mathrm{D}_{2} \mathrm{O}\right.$ exchangeable). The $\mathrm{AB}$ system due to the 4-chlorophenyl nucleus $(4 \mathrm{H})$ gave two doublets (each with $\mathrm{J}_{\mathrm{HH}}=8.4 \mathrm{~Hz}$ ) at 7.35 and $7.40 \mathrm{ppm}$. 
c- The mass spectrum of $(R)$-20 (Scheme 7) showed the molecular ion peak at $\mathrm{m} / \mathrm{z} 186\left(22 \%\right.$ based on $\left.{ }^{35} \mathrm{Cl}\right)$ and at $188\left(7 \%\right.$ based on $\left.{ }^{37} \mathrm{Cl}\right)$. Loss of $\mathrm{OH}$ radical from $\mathrm{M}^{+}$yields cation a at $\mathrm{m} / \mathrm{z} 169,2 \%(171, \%)$. Meanwhile, loss of $\mathrm{COOH}$ radical from $\mathrm{M}^{+}$affords cation $\mathrm{b}$ at $\mathrm{m} / \mathrm{z} 141$ (base peak) and $143(52 \%)$. The spectrum also showed ion peaks at $\mathrm{m} / \mathrm{z} 111(17 \%)$ and $113(10 \%)$ for the 4-chlorophenyl cation and at $\mathrm{m} / \mathrm{z} 75$ which corresponds to the cation of hydroxyacetic acid (Scheme 7).

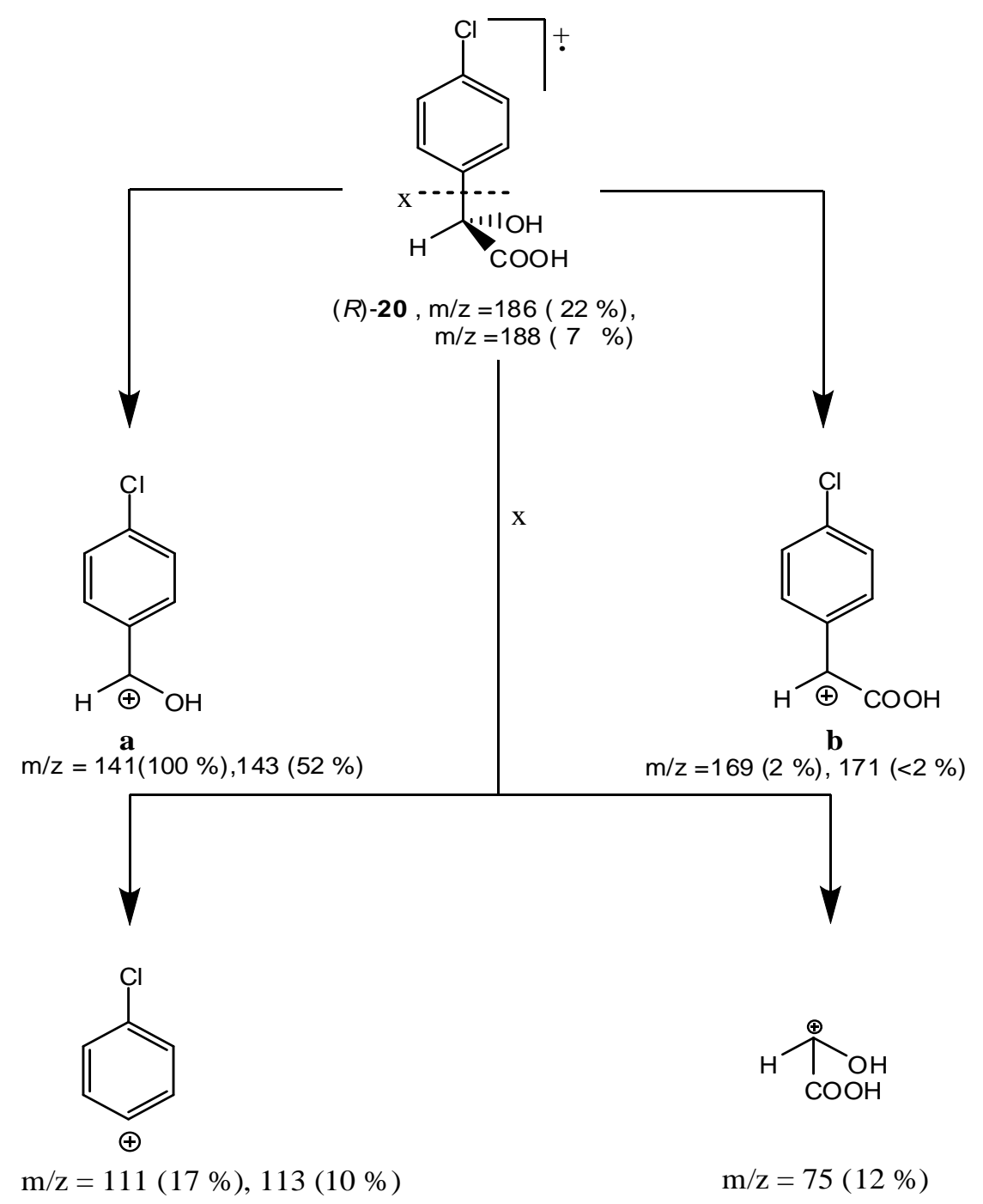

Scheme 7

Egypt. J. Chem. 53, No. 5 (2010) 
Hydrocyanation of ketones $2 a, b$

The non-enzyme and enzyme catalyzed cyanuration of cyclohexanone $2 \mathrm{a}$ and 2 -methyl cyclohexanone $2 \mathrm{~b}$ afforded the respective racemic and optically active cyanohydrins $(R, S)-21 \mathrm{a}$ and $(R)-21 \mathrm{~b}($ Scheme 8$)$.

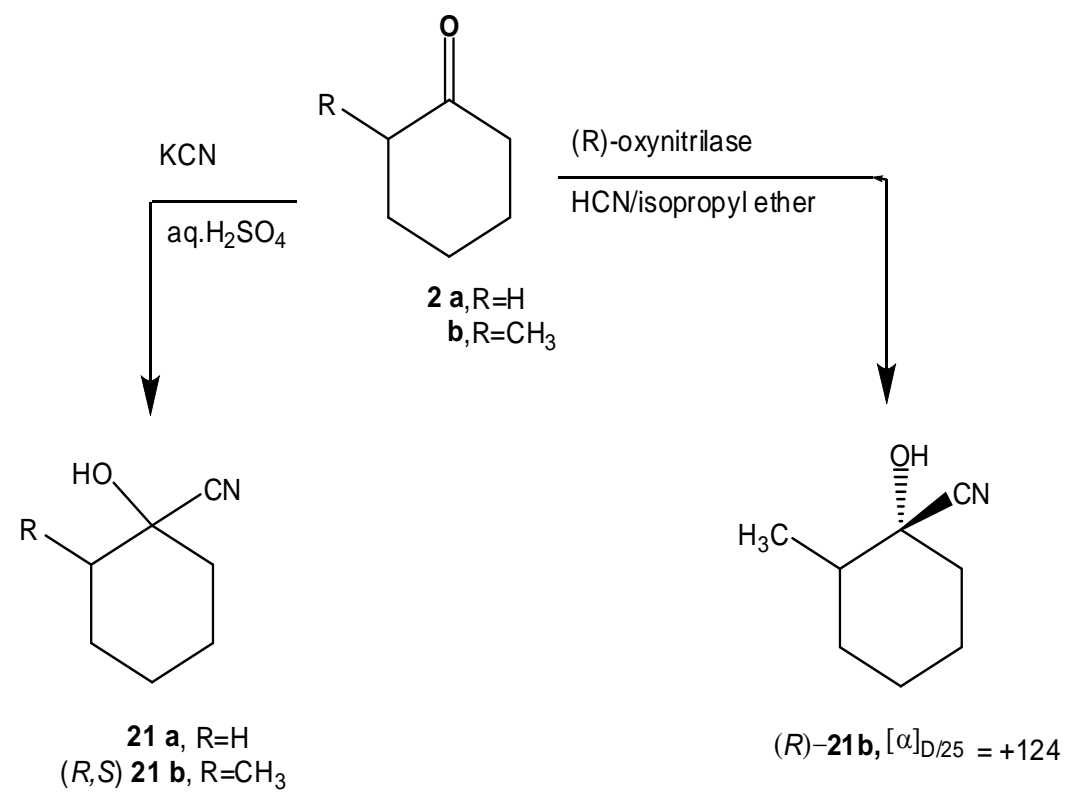

\section{Scheme 8}

The racemic $(R, S)-21 \mathrm{a}, \mathrm{b}$ and optically active $(R)-21 \mathrm{~b}$ forms undergo a number of transformations which involve either the hydroxyl group or the cyanofunction in their molecules (Scheme 9 ). Thus, derivatization of $(R)-21 \mathrm{~b}$ with $(S)$ Naproxen chloride $(S)-7$ proceeded in $\mathrm{CH}_{2} \mathrm{Cl}_{2}$ in the presence of pyridine to give the respective diastereoisomer, namely, $(2 S)-((1 R)$-1-cyano -2-methylcyclohex 1-yl) -2-(6-methoxynaphthalen-2-yl)- propanoate $(1 R, 2 S)-22 \mathrm{~b}$. Elementary and molecular weight determination (MS) for $(1 R, 2 S)-22 \mathrm{~b}$ corresponded to $\mathrm{C}_{22} \mathrm{H}_{25} \mathrm{NO}_{3}$. Its structural reasonings are :

(i) The IR spectrum $\left(\mathrm{KBr}, \mathrm{cm}^{-1}\right)$ disclosed the presence of strong absorption bands at 3057 (C-H, aromatic), 2936, 2862 (C-H, aliphatic), $2237(\mathrm{C} \equiv \mathrm{N}) ; 1744$ $(\mathrm{C}=\mathrm{O}$, ester $), 1631,1606(\mathrm{C}=\mathrm{C}$, aromatic $)$ and $1222(\mathrm{C}-\mathrm{O}$, ester $)$.

(ii) Its ${ }^{1} \mathrm{H}$ NMR spectrum $\left(\mathrm{CDCl}_{3}, \delta \mathrm{ppm}\right)$ showed signals at $0.81\left(3 \mathrm{H}, \mathrm{Cb}-\mathrm{CH}_{3}, \mathrm{~d}\right.$, $\left.\mathrm{J}_{\mathrm{HH}}=6.9 \mathrm{~Hz}\right), 1.56\left(\mathrm{CH}_{3}-\mathrm{CH}-\mathrm{C}=\mathrm{O}, \mathrm{d}, \mathrm{J}_{\mathrm{HH}}=6.9 \mathrm{~Hz}\right), 3.84\left(\mathrm{CH}_{3}-\mathrm{CH}-\mathrm{C}=\mathrm{O}, \mathrm{q}\right.$, $\left.\mathrm{J}_{\mathrm{HH}}=6.9 \mathrm{~Hz}\right)$ and $1.21-2.12(8 \mathrm{H}$, cyclohexyl protons $\mathrm{c}-\mathrm{f}, \mathrm{m}), 2.75(1 \mathrm{H}, \mathrm{Cb}-\mathrm{H}, \mathrm{m}]$, $3.91\left(3 \mathrm{H}, \mathrm{OCH}_{3}, \mathrm{~s}\right)$ and $7.14-7.78(6 \mathrm{H}$, aromatic protons i,j-m,0,p, m).

(ii) The mass spectrum of $(1 R, 2 S)-22 \mathrm{~b}$ showed the molecular ion peak at $\mathrm{m} / \mathrm{z}$ $351(10 \%)$.

Egypt. J. Chem. 53, No. 5 (2010) 


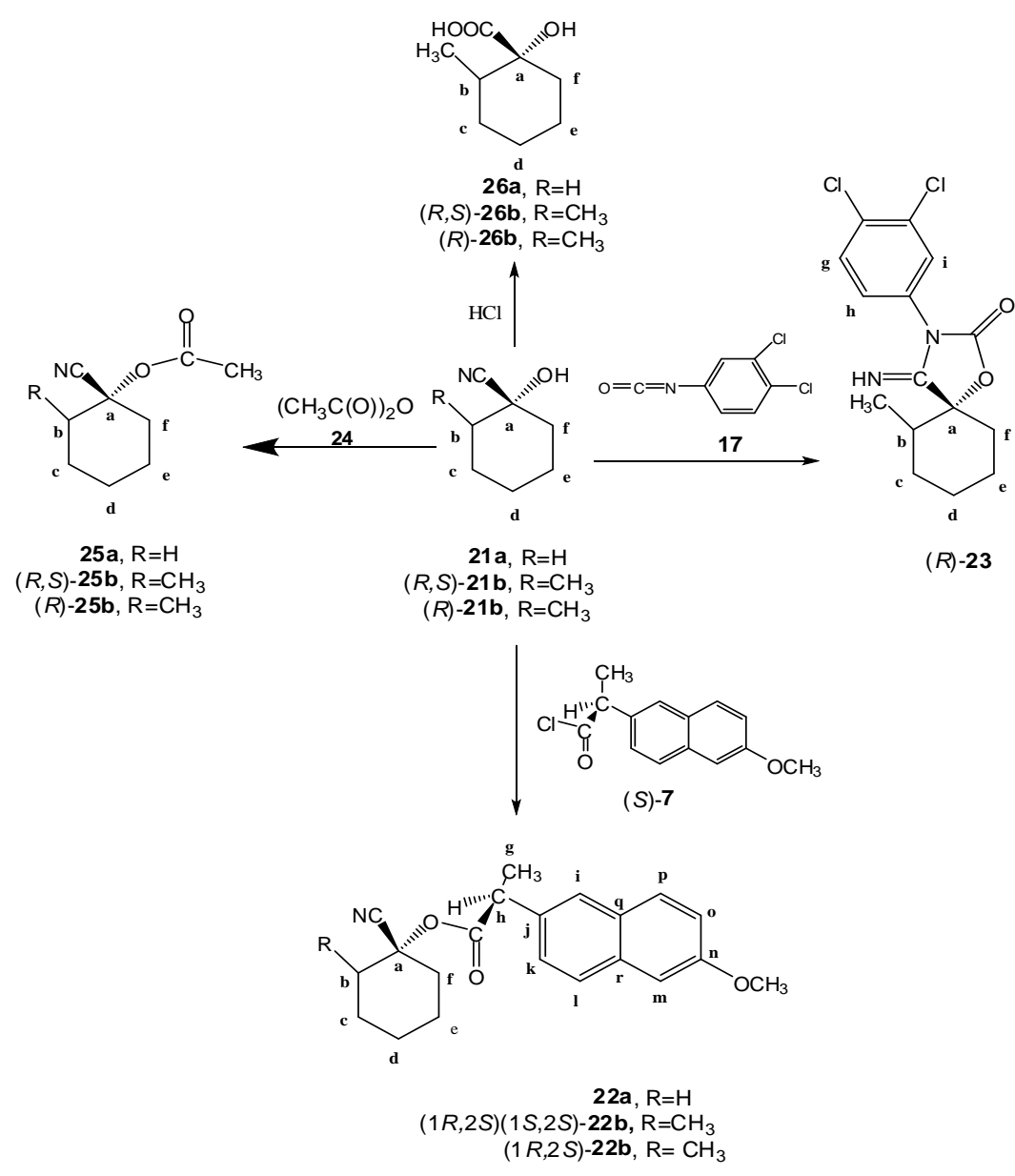

Scheme 9

Treatment of $(R)-21 \mathrm{~b}$ with 3,4-dichlorophenyl isocyanate (17) yielded (5R)3-(3,4-dichlorophenyl)-5-(2-methylcyclohex-1-yl)-4-iminooxazolidin-2-one $(R)$ 23. Compatible elementary and molecular weight determination (MS) for $(R)-23$, corresponded to $\mathrm{C}_{15} \mathrm{H}_{16} \mathrm{Cl}_{2} \mathrm{~N}_{2} \mathrm{O}_{2}$. Its IR spectrum $\left(\mathrm{KBr}, \mathrm{cm}^{-1}\right)$ showed strong absorption bands at $3422(\mathrm{~N}-\mathrm{H}), 3077(\mathrm{C}-\mathrm{H}$, aromatic), 2927, $2856(\mathrm{C}-\mathrm{H}$, aliphatic), $1727(\mathrm{C}=\mathrm{O}$, ester $), 1677(\mathrm{C}=\mathrm{N}$, exocyclic $)$ and $1590 \quad(\mathrm{C}=\mathrm{C}$, aromatic). Its ${ }^{1} \mathrm{H}$ NMR spectrum (DMSO- $\left.\mathrm{d}_{6}, \delta \mathrm{ppm}\right)$ showed signals at $0.96(3 \mathrm{H}$, $\left.\mathrm{Cb}-\mathrm{CH}_{3}, \mathrm{~d}, \mathrm{~J}_{\mathrm{HH}}=6.9 \mathrm{~Hz}\right) ; 1.21-2.21(8 \mathrm{H}$, cyclohexyl protons c-f, m), $2.49(\mathrm{Cb}-$ $H, \mathrm{~m})$ and at 7.34, 7.40, $7.61(3 \mathrm{H}$, aromatic g,i,h protons $)$ the $\mathrm{NH}$ proton gave a $\mathrm{D}_{2} \mathrm{O}$-exchangeable broad singlet at $6.09 \mathrm{ppm}$. 
Acetylation of $21 \mathrm{a},(R, S)-21 \mathrm{~b}$ and $(R)-21 \mathrm{~b}$ with acetic anhydride 24 produced the respective esters $25 \mathrm{a},(R, S)-25 \mathrm{~b}$ and $(R)-25 \mathrm{~b}$.

Upon heating 21a, $(R, S)-21 \mathrm{~b}$ and $(R)-21 \mathrm{~b}$ with concentrated hydrochloric acid, they yielded the respective hydroxycarboxylic acids $26 \mathrm{a},(R, S)-26 \mathrm{~b}$ and $(R)-26 \mathrm{~b}$. For example, compatible elementary and molecular weight determination (MS) for $(R)-(+)$-1-hydroxy-2-methylcyclohexane carboxylic acid $(R)-26 \mathrm{~b}$ corresponded to $\mathrm{C}_{8} \mathrm{H}_{14} \mathrm{O}_{3}, \mathrm{MS} \mathrm{m} / \mathrm{z}: 158(20 \%)$. Its IR spectrum $\left(\mathrm{KBr}, \mathrm{cm}^{-1}\right)$ showed strong absorption bands at 3458 and $3340(\mathrm{O}-\mathrm{H}), 2949$ and $2884(\mathrm{C}-\mathrm{H}$, aliphatic and alicyclic), $1705 \quad(\mathrm{C}=\mathrm{O})$ and at $1248\left(\mathrm{C}-\mathrm{O}\right.$, acid). Its ${ }^{1} \mathrm{H}$ NMR specterum $\left(\mathrm{DMSO}_{6} \mathrm{~d}_{6}, \delta \mathrm{ppm}\right)$ showed signals at $6.25\left(1 \mathrm{H}, \mathrm{OH}, \mathrm{D}_{2} \mathrm{O}\right.$-exchangeable $), 6.80$ ( $1 \mathrm{H}, \mathrm{COOH}, \mathrm{D}_{2} \mathrm{O}$ - exchangeable) $0.77\left(3 \mathrm{H}, \mathrm{Cb}-\mathrm{CH}_{3}, \mathrm{~d}_{\mathrm{HH}}=6.9 \mathrm{~Hz}\right), 0.89-1.89$ $(8 \mathrm{H}$, cyclohexyl c-f protons, $\mathrm{m})$ and $2.01(1 \mathrm{H}, \mathrm{Cb}-\mathrm{CH}, \mathrm{m})$.

The mass spectrum of compound $(R)-26 \mathrm{~b}$ (Scheme 10) showed the molecular ion peak at $\mathrm{m} / \mathrm{z} 158$ (base peak). Loss of water molecule from $\mathrm{M}^{+}$can afford the radical cation a (or b) at $\mathrm{m} / \mathrm{z} 140$. The molecular ion peak can also lose one hydrogen molecule to give radical cation e (or f) at $\mathrm{m} / \mathrm{z} 156$. Loss of $\mathrm{COOH}$ radical from $\mathrm{M}^{+}$yields cation $\mathrm{c}$ at $\mathrm{m} / \mathrm{z} 113$. Meanwhile, loss of $\mathrm{OH}$ radical from $\mathrm{M}^{+}$yields cation $\mathrm{d}$ at $\mathrm{m} / \mathrm{z} 141$. Cation $\mathrm{g}$ at $\mathrm{m} / \mathrm{z} 114$ can result via expulsion of $\mathrm{CO}_{2}$ molecule from the molecular ion peak. This is evidenced by presence of a prominent ion at $\mathrm{m} / \mathrm{z} 44(86 \%)$ due to radical cation of $\mathrm{CO}_{2}$ which is also frequent in the mass spectra of several carboxylic acid derivatives ${ }^{(6)}$.

\section{Biological Results}

The anticancer activity of selected newly synthesized compounds was investigated. The evaluations for in vitro cytotoxicity of the investigated compounds were carried out against a panel of three human solid tumor cell lines which are HCT116 (colon carcinoma cell line), HEPG2 (liver carcinoma cell line) and MCF (breast carcinoma cell line). The sulphorhodamine-B method ${ }^{(35)}$ was used for the assay of the cytotoxic activity and Doxorubicin ${ }^{(36)}$ drug was used as a standard. The Doxorubicin cytotoxicity appears to be due to its ability to intercalate with DNA, interact with plasma membrane and to take part in oxidation-reduction reactions ${ }^{(37)}$.

The investigation showed that there is a structure-activity relationship (SAR). For example, the screening of the investigated compounds against HCT-116 cell line showed that the optically active compound $(R)-14$ (Chart $2)$ is more active than its racemic form $(R, S)-14$ (Chart 3). Both $(R)-14$ and $(R, S)-14$ are more active than compound $(R, S)-16$ which show the effect of presence of a chlorine atom in this structure. Similarly, compound $22 \mathrm{~b}$ in its optically active form (Chart 6) is more active than its racemic analogou $(1 R, 2 S)(1 S, 2 S)-22 \mathrm{~b}$ (Chart 7$)$. Based on these results, there is a marked difference in the activity of a given optically active compound in comparison to that of its racemic form which reflects the influence of the optical purity on the biological activity.

Egypt. J. Chem. 53, No. 5 (2010) 


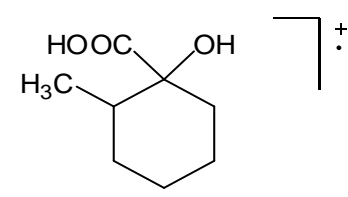

(R)-26b, $\mathrm{M}^{+}, \mathrm{C}_{8} \mathrm{H}_{14} \mathrm{O}_{3}, \mathrm{~m} / \mathrm{z} 158$ (100\%, base peak)<smiles>CC1CCCCC1O</smiles>

c, $\mathrm{C}_{17} \mathrm{H}_{13} \mathrm{O}, \mathrm{m} / \mathrm{z} 113(85 \%)$<smiles>CC1CCCC[C+]1C(=O)O</smiles>

d, $\mathrm{C}_{8} \mathrm{H}_{13} \mathrm{O}_{2}, \mathrm{~m} / \mathrm{z} 141$ (27\%)<smiles>C[C+]CC1(O)CCCC=C1C</smiles>

e

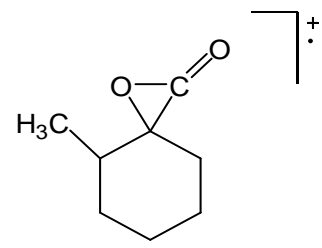

a, $\mathrm{C}_{8} \mathrm{H}_{12} \mathrm{O}_{2}, \mathrm{~m} / \mathrm{z} 140$ (87\%)

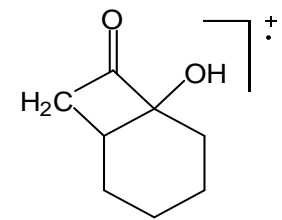

b, $\mathrm{C}_{8} \mathrm{H}_{12} \mathrm{O}_{2}, \mathrm{~m} / \mathrm{z} 140$ (87\%)

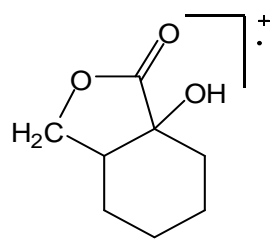<smiles>C[C]C1CCCCC1C</smiles>

g, $\mathrm{C}_{7} \mathrm{H}_{14} \mathrm{O}, \mathrm{m} / \mathrm{z} 114$ (19\%)

Scheme 10

Egypt. J. Chem. 53, No. 5 (2010) 


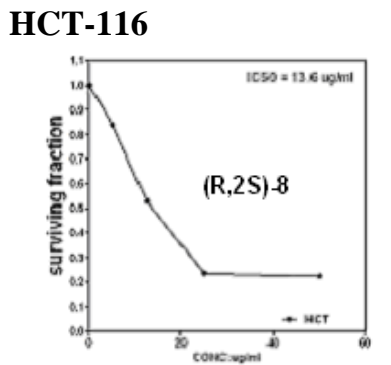

(Chart 1)

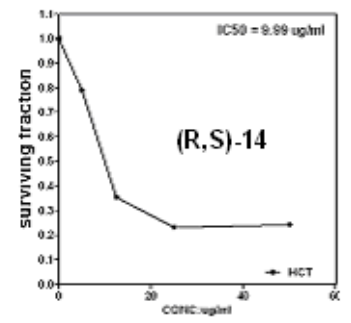

(Chart 3)

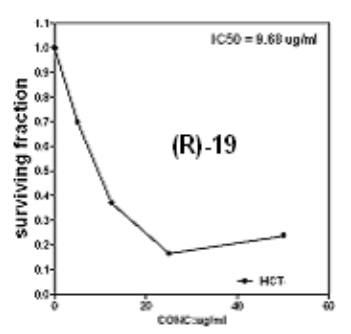

(Chart 5)

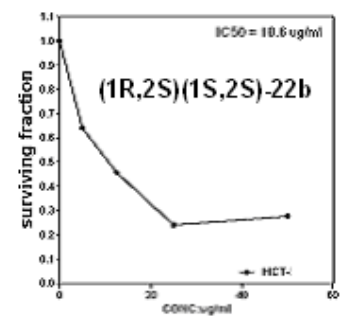

(Chart 7)

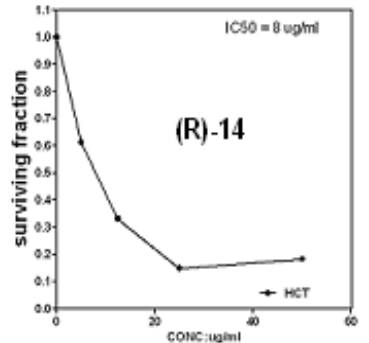

(Chart 2)

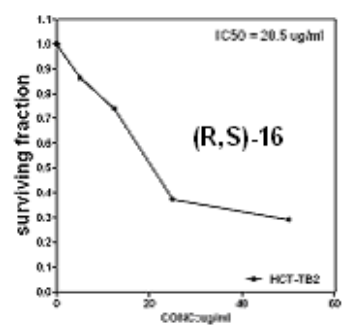

(Chart 4)

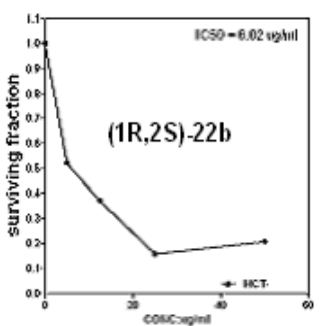

(Chart 6)

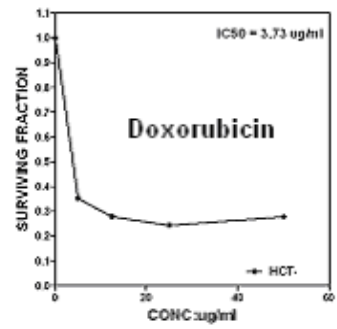

(Chart 8)

Egypt. J. Chem. 53, No. 5 (2010) 
HEPG-2
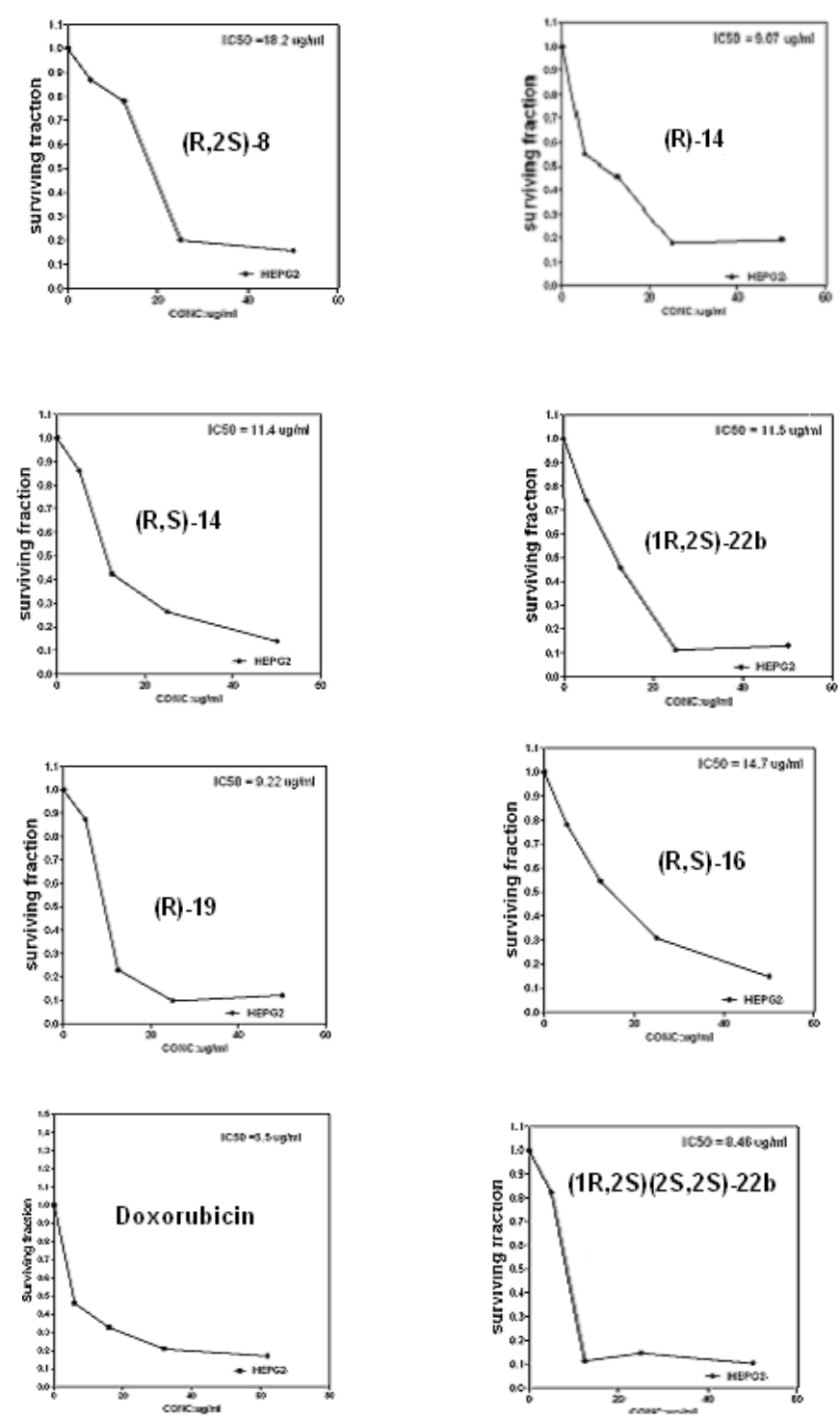

Egypt. J. Chem. 53, No. 5 (2010) 
MCF-7
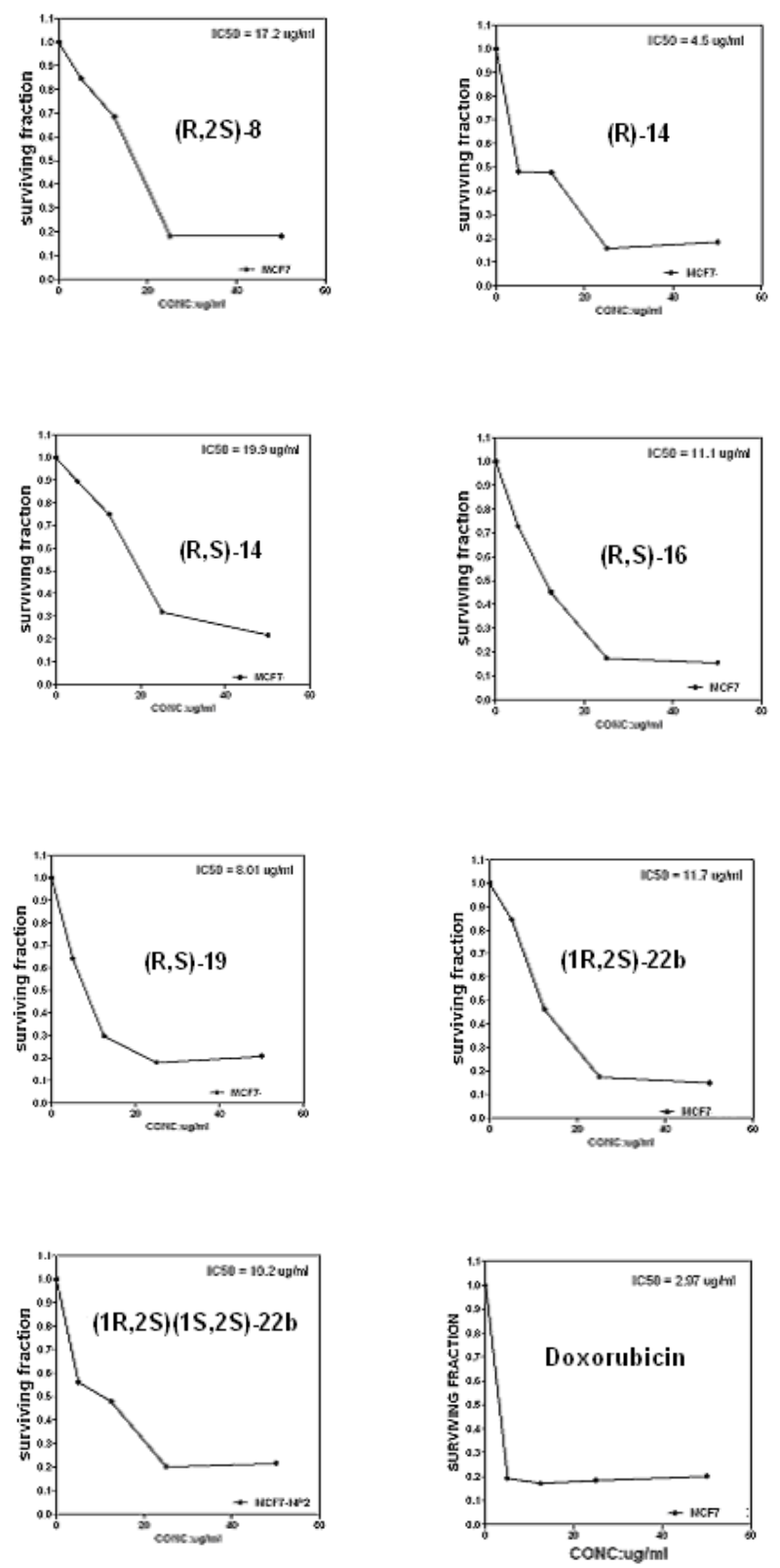

Egypt. J. Chem. 53, No. 5 (2010) 


\section{Experimental}

Reactions with air-sensitive reagents were carried out in flame-dried glassware under dry argon atmosphere. The liquid reagents were added using the syringe technique. Solvents were rigorously dried and purified according to usual procedures. The reacting aldehydes and ketones were purified directly before use by distillation and/or crystallization. The almond meal and the isolated cyanohydrins were stored at $-15{ }^{\circ} \mathrm{C}$. $(R)$ - Oxynitrilase enzyme (HNL) [EC4.1.2.10] was extracted ${ }^{(38)}$, assayed and its activity was measured ${ }^{(39)}$ according to the given procedures. The reactions were monitored (TLC) and the purity of the isolated products were controlled by using silica gel with fluorescent indicator $\mathrm{F}_{254}$ coated on aluminum sheets of layer thickness $0.2 \mathrm{~mm}$ [Fluka]. The products were isolated and purified by preparative thin layer chromatography: on glass plates $(20 \times 20 \mathrm{~cm})$ coated with silica gel 60 with fluorescent indicator $\mathrm{F}_{254}$.

$p \mathrm{H}-\mathrm{Values}$ were determined by Precisa Digital pH-Meter $\mathrm{pH} 900$ with $\mathrm{Ag} / \mathrm{AgCl}$ electrode. The activity of enzyme was measured by Schimadzu UV2401 PC UB-VIS Recording Spectrophotometer. Optical Rotations were performed in: Carl Zeiss 212503 Polarometer, at The Chemical Industries Development Co. (CID) and / or ATAGO Polax-2L, USA, Code $=\mathrm{OC}_{50 R_{7}}$ and A. K RÜSS, Opt. Ronic, Germany at the National Research Centre. $[\alpha]_{D / 25}=\alpha /$ c.d, Path length $(\mathrm{d})=10 \mathrm{~cm}$, Concentration (c) $=10 \mathrm{mg} / \mathrm{ml} \alpha$ is the measured angle of rotation and $[\alpha]$ is the specific rotation expressed in $\left({ }^{\circ} . \mathrm{L}\right)(\mathrm{Kg} . \mathrm{dm})$. Melting points are uncorrected and recorded on Stuart SMP1 apparatus. Infrared Spectra were performed either neat or in $\mathrm{KBr}$ discs using: JASCO FT/IR-300E Fourier Transform Infrared Spectrophotometer, National Research Centre and / or Bruker Vector 22 Spectrophoto- meter, Microanalysis Centre, Cairo University. The spectra were reported in $\mathrm{cm}^{-1}$.

${ }^{1} \mathrm{H}$ NMR spectra were recorded on Varian Gemini 200 equipment operating at $200 \mathrm{MHz}$, Microanalysis Centre, Cairo University and/or JOEL JNM-EX 270 (at $270 \mathrm{MHz}$ ) and JOEL $500 \mathrm{AS}$ (at $500 \mathrm{MHz}$ ) equipments, National Research Centre. The spectra were obtained from deuterated chloroform $\left(\mathrm{CDCl}_{3}\right)$ and/or deuterated dimethylsulphoxide (DMSO- $\mathrm{d}_{6}$ ) and the chemical shifts were reported in $\delta$ ppm units downfield from tetramethylsilane (TMS). ${ }^{13} \mathrm{C}$ NMR spectra were recorded on JOEL $500 \mathrm{AS}$ (at $125 \mathrm{MHz}$ ) equipment, National Research Centre. The Mass Spectra were recorded on Finnigan SSQ 7000 Spectrometer at $70 \mathrm{eV}$ (Electron Impact). The enantiomeric excess ee \% was obtained after derivatization of cyanohydrins with Naproxen chloride to the corresponding diasteroisomers whose ratios were determined with ${ }^{1} \mathrm{H}$ NMR by quantitative analysis of the spectral data through comparable evaluation of the integral level for both diastreoisomers. X-Ray diffraction: The intensity data was performed with a Kappa-CCD Enraf Nonius FR 590 Single Crystal Diffractometer. The structure was solved by direct methods using the SIR92 program ${ }^{(40)}$ and 
refined using maXus ${ }^{(41)}$. The molecular graphics were made with ORTEP ${ }^{(42)}$. Crystallographic data (CIF) for the structure reported in this article have been deposited in the Cambridge Crystallographic Data Centre (CCDC) as supplementary publication No. CCDC 801828. Copies of the data can be obtained, free of charge, upon application to the CCDC, 12 Union Road, Cambridge CB 12EZ, UK.

(FAX: + 44(1223)336-033; E-mail:deposit@ccdc.cam.ac.uk).

\section{Synthesis of the racemic cyanohydrins}

General procedure

In a three necked flask equipped with a mechanical stirrer and a dropping funnel, a saturated solution of sodium metabisulphite $(150 \mathrm{~g}$ in $200 \mathrm{ml}$ water $)$ was added dropwise to a mixture of the appropriate carbonyl compound (aldehyde and/or ketone) ( 0.25 mole) and potassium cyanide solution ( 0.3 mole in $50 \mathrm{ml}$ of distilled water). During the initial stages of addition, the reaction mixture was cooled by adding crushed ice in several portions through the third neck. After completion of addition (about $30 \mathrm{~min}$ ), the reaction mixture was stirred for further $12 \mathrm{hr}$ at room temperature then extracted with diethyl ether $(3 \times 100 \mathrm{ml})$. The combined organic extracts were washed with water $(2 \times 50 \mathrm{ml})$ and dried over anhydrous sodium sulphate. After removal of the solid materials, the ether filtrate was evaporated well in vacuo to leave the corresponding racemic cyanohydrin.

\section{(R,S)-2-(4-chlorophenyl) )-2-hydroxyethanenitrile $(R, S)$-3}

Yellow oil, yield 87\%. IR (neat, $\left.\mathrm{cm}^{-1}\right): 3390(\mathrm{O}-\mathrm{H}) ; 3095(\mathrm{C}-\mathrm{H}$, aromatic); 2906 (C-H aliphatic, asymmetric), 2808 (C-H aliphatic, symmetric); 2254 $(\mathrm{C} \equiv \mathrm{N}) ; 1595(\mathrm{C}=\mathrm{C}$, aromatic); $1091(\mathrm{C}-\mathrm{Cl}$, aromatic) and $1039(\mathrm{C}-\mathrm{O}$, alcohol). ${ }^{1} \mathrm{H}-\mathrm{NMR}\left(\mathrm{CDCl}_{3}, \delta \mathrm{ppm}\right): 4.69\left(\mathrm{OH}, \mathrm{D}_{2} \mathrm{O}\right.$ exchangeable); $5.48(\mathrm{NC}-\mathrm{CH}, \mathrm{s})$; $7.29\left(2 \mathrm{H}\right.$, aromatic protons meta to the $\mathrm{Cl}$ atom, $\mathrm{AB}$ system, $\left.\mathrm{d}, \mathrm{J}_{\mathrm{HH}}=8.4 \mathrm{~Hz}\right)$ and $7.33\left(2 \mathrm{H}\right.$, aromatic protons ortho to the $\mathrm{Cl}$ atom, $\mathrm{AB}$ system, $\left.\mathrm{d}, \mathrm{J}_{\mathrm{HH}}=8.4 \mathrm{~Hz}\right)$.

$(R, S)$-2-phenyl-2-hydroxy ethanenitrile $(R, S)-15^{(34)}$ :

Yellow oil, yield 88\%. IR (neat, $\left.\mathrm{cm}^{-1}\right): 3382(\mathrm{O}-\mathrm{H}) ; 3091(\mathrm{C}-\mathrm{H}$, aromatic); 2922 (C-H aliphatic, asymmetric), 2818 (C-H aliphatic, symmetric); 2255 $(\mathrm{C} \equiv \mathrm{N}) ; 1598\left(\mathrm{C}=\mathrm{C}\right.$, aromatic) and $1044\left(\mathrm{C}-\mathrm{O}\right.$, alcohol). ${ }^{1} \mathrm{H}$ NMR $\left(\mathrm{CDCl}_{3}\right): 4.72$ $\left(\mathrm{OH}, \mathrm{D}_{2} \mathrm{O}\right.$ exchangeable $) 5.46(1 \mathrm{H}, \mathrm{NC}-\mathrm{CH}, \mathrm{s}) ; 7.42(1 \mathrm{H}$, para aromatic proton, $\left.\mathrm{t}, \mathrm{J}_{\mathrm{HH}}=3.1 \mathrm{~Hz}\right) ; 7.44\left(2 \mathrm{H}\right.$, ortho aromatic protons, $\left.\mathrm{t}, \mathrm{J}_{\mathrm{HH}}=6.1 \mathrm{~Hz}\right) ; 7.52(2 \mathrm{H}$, meta aromatic protons, $\mathrm{dt}, \mathrm{J}_{\mathrm{HH}}=6.1 \mathrm{~Hz}, \mathrm{~J}_{\mathrm{HH}}=3.1 \mathrm{~Hz}$ ).

\section{Cyclohexanone cyanohydrin (21a)}

Colourless oil, yield $78 \%$. IR (neat, $\mathrm{cm}^{-1}$ ): $3429(\mathrm{O}-\mathrm{H}) ; 2932$ (asymmetric $\mathrm{C}-\mathrm{H}$ aliphatic); 2871 (symmetric $\mathrm{C}-\mathrm{H}$ aliphatic); $2235(\mathrm{C} \equiv \mathrm{N}) ; 1074(\mathrm{C}-\mathrm{O}$, alcohol). ${ }^{1} \mathrm{H}$ NMR $\left(\mathrm{CDCl}_{3}\right): 1.42-1.54(6 \mathrm{H}, \mathrm{C} 3, \mathrm{C} 4, \mathrm{C} 5$ protons, $\mathrm{m}) ; 1.81(2 \mathrm{H}$, $\mathrm{C} 2$, C6 axial protons, dt, $\left.\mathrm{J}_{\mathrm{HHgem}}=12.8 \mathrm{~Hz}, \mathrm{~J}_{\mathrm{HHvic}}=6.9 \mathrm{~Hz}\right) ; 2.05(2 \mathrm{H}, \mathrm{C} 2, \mathrm{C} 6$ equatorial protons, dt, $\left.\mathrm{J}_{\mathrm{HHgem}}=13.1 \mathrm{~Hz}, \mathrm{~J}_{\mathrm{HHvic}}=6.9 \mathrm{~Hz}\right)$ and $5.59\left(1 \mathrm{H}, \mathrm{OH}, \mathrm{D}_{2} \mathrm{O}\right.$ exchangeable).

Egypt. J. Chem. 53, No. 5 (2010) 
$(R, S)-2-M e t h y l c y c l o h e x a n o n e ~ c y a n o h y d r i n(R, S)-21 b$

Colourless oil, yield $83 \%$. IR (neat, $\left.\mathrm{cm}^{-1}\right)$ : $3423(\mathrm{O}-\mathrm{H}) ; 2936(\mathrm{C}-\mathrm{H}$ aliphatic asymmetric); $2863(\mathrm{C}-\mathrm{H}$ aliphatic, symmetric); $2237(\mathrm{C} \equiv \mathrm{N}) ; 1074(\mathrm{C}-$ $\mathrm{O}$, alcohol). ${ }^{1} \mathrm{H} \mathrm{NMR}\left(\mathrm{CDCl}_{3}\right): 0.72\left(3 \mathrm{H}, \mathrm{C} 2-\mathrm{CH}_{3}, \mathrm{~d}, \mathrm{~J}_{\mathrm{HH}}=6.9 \mathrm{~Hz}\right) ; 1.27-1.53$ $(6 \mathrm{H}, \mathrm{C} 3, \mathrm{C} 4, \mathrm{C} 5$ protons, $\mathrm{m}) ; 1.78\left(1 \mathrm{H}, \mathrm{C} 6\right.$ axial proton, dt, $\mathrm{J}_{\mathrm{HHgem}}=12.8 \mathrm{~Hz}$, $\left.\mathrm{J}_{\mathrm{HHvic}}=6.8 \mathrm{~Hz}\right) ; 2.03\left(1 \mathrm{H}, \mathrm{C} 6\right.$ equatorial proton, $\mathrm{dt}, \mathrm{J}_{\mathrm{HHgem}}=12.8 \mathrm{~Hz}$, $\left.\mathrm{J}_{\mathrm{HHvic}}=6.9 \mathrm{~Hz}\right) ; 2.71(1 \mathrm{H}, \mathrm{C} 2-\mathrm{H}, \mathrm{m})$ and $5.52\left(1 \mathrm{H}, \mathrm{OH}, \mathrm{D}_{2} \mathrm{O}\right.$ exchangeable $)$.

Synthesis of the racemic cyanohydrins using acetone cyanohydrin as a transcyanating agent ${ }^{(26)}$

To a stirred solution of the appropriate carbonyl compound $(0.1 \mathrm{~mole})$ in diisopropyl ether $(20 \mathrm{ml})$, acetone cyanohydrin (4) was added dropwise followed by sodium hydroxide ( $15 \mathrm{ml}$ of $1 \mathrm{M}$ solution) at room temperature. The reaction mixture was stirred for $6 \mathrm{hr}$ then followed-up as described in the previous general procedure to give the cyanohydrins $(R, S)-3,21 \mathrm{a}$ and $(R, S)-21 \mathrm{~b}$ in yields of 78, 68 and $57 \%$, respectively.

\section{Synthesis of the optically active cyanohydrins}

\section{Step 1: Preparation of hydrogen cyanide solution ${ }^{(43)}$}

Orthophosphoric acid $(0.2$ mole, $13.7 \mathrm{ml})$ was added dropwise with stirring to a solution of potassium cyanide $(0.2$ mole, $13 \mathrm{~g})$ in distilled water $(30 \mathrm{ml})$ and diisopropyl ether $(50 \mathrm{ml})$ over a period of $5 \mathrm{~min}$ at $0^{\circ} \mathrm{C}$. After stirring the reaction mixture for further $15 \mathrm{~min}$, the cooling bath was removed and the ethereal layer was separated off.

Step 2: Addition of hydrogen cyanide solution to the carbonyl compounds 1 and $2 a, b$

General procedure: The ethereal solution of hydrogen cyanide was added dropwise at $0^{\circ} \mathrm{C}$ under stirring with a mechanical stirrer to a mixture of the crude enzyme extract and the carbonyl compound 1 and /or $2 b$ in diisopropyl ether $(30 \mathrm{ml})$. After completion of addition $(30 \mathrm{~min})$, the reaction mixture was stirred for further $24 \mathrm{hr}$. The cooling bath was removed and the reaction mixture was stirred vigorously with a saturated solution of sodium chloride $(200 \mathrm{ml})$ and diisopropyl ether $(100 \mathrm{ml})$ for $30 \mathrm{~min}$. The ethereal layer was separated, washed with distilled water $(2 \times 50 \mathrm{ml})$ and dried over anhydrous sodium sulphate. After removal of the solid material, the ethereal solution was evaporated well in vacuo to give the respective optically active cyanohydrin $(R)-3$ or $(R)-21 \mathrm{~b}$.

\section{(R)-2-(4-chlorophenyl)-2-hydroxyethanenitrile $(R)-3$}

Enantiomeric excess (ee) $94 \%,[\alpha]_{\mathrm{D} / 25}=+178$. Yellow oil, yield $98 \%$. IR (neat, $\left.\mathrm{cm}^{-1}\right): 3390(\mathrm{O}-\mathrm{H}) ; 3095(\mathrm{C}-\mathrm{H}$, aromatic); $2906(\mathrm{C}-\mathrm{H}$ aliphatic); 2254 $(\mathrm{C} \equiv \mathrm{N}), 1595(\mathrm{C}=\mathrm{C}$ aromatic $) ; 1091(\mathrm{C}-\mathrm{Cl}$, aromatic) and $1039(\mathrm{C}-\mathrm{O}$ alcohol). ${ }^{1} \mathrm{H}-\mathrm{NMR}\left(\mathrm{CDCl}_{3}\right): 4.44\left(1 \mathrm{H}, \mathrm{OH}, \mathrm{D}_{2} \mathrm{O}\right.$-exchange- able); $5.46(1 \mathrm{H}, \mathrm{NC}-\mathrm{C}-\mathrm{H}, \mathrm{s})$; $7.34\left(2 \mathrm{H}\right.$, aromatic protons $m$ to the $\mathrm{Cl}$ atom, $\mathrm{AB}$ system, $\left.\mathrm{d}, \mathrm{J}_{\mathrm{HH}}=8.3 \mathrm{~Hz}\right)$ and 7.37 ( $2 \mathrm{H}$, aromatic protons $o$ to the $\mathrm{Cl}$ atom, $\mathrm{AB}$ system, $\mathrm{d}, \mathrm{J}_{\mathrm{HH}}=8.3 \mathrm{~Hz}$ ). 
(R)-2-methylcyclohexanone cyanohydrin $(R)-21 b$

Colourless oil, yield $88 \%$. IR (neat, $\left.\mathrm{cm}^{-1}\right)$ : $3441(\mathrm{O}-\mathrm{H}) ; 2926(\mathrm{C}-\mathrm{H}$ aliphatic, asymmetric); 2860 (C-H aliphatic, symmetric); $2237(\mathrm{C} \equiv \mathrm{N}) ; 1069(\mathrm{C}-$ $\mathrm{O}$, alcohol). ${ }^{1} \mathrm{H} \mathrm{NMR}\left(\mathrm{CDCl}_{3}\right): 0.82\left(3 \mathrm{H}, \mathrm{C} 2-\mathrm{CH}_{3}, \mathrm{~d}, \mathrm{~J}_{\mathrm{HH}}=6.9 \mathrm{~Hz}\right) ; 1.33-1.54$ $(6 \mathrm{H}, \mathrm{C} 3, \mathrm{C} 4, \mathrm{C} 5$ protons, $\mathrm{m}) ; 1.78\left(1 \mathrm{H}, \mathrm{C} 6-\boldsymbol{H}\right.$ axial, dt, $\mathrm{J}_{\mathrm{HHgem}}=12.8 \mathrm{~Hz}$, $\left.\mathrm{J}_{\mathrm{HHvic}}=6.8 \mathrm{~Hz}\right) ; 2.04\left(1 \mathrm{H}, \mathrm{C} 6-H\right.$ equatorial, dt, $\left.\mathrm{J}_{\mathrm{HHgem}}=12.8 \mathrm{~Hz}, \mathrm{~J}_{\mathrm{HHvic}}=6.9 \mathrm{~Hz}\right)$; $2.72(1 \mathrm{H}, \mathrm{C} 2-H, \mathrm{~m})$ and $5.59\left(1 \mathrm{H}, \mathrm{O}-\mathrm{H}, \mathrm{D}_{2} \mathrm{O}\right.$ exchangeable).

Preparation of optically active cyanohydrins using acetone cyanohydrin as a transcyanating agent

Acetone cyanohydrin (4) $(0.015$ mole, $1.2 \mathrm{ml})$ was added to a mixture of the carbonyl compound 1 or $2 \mathrm{~b}$ and the crude enzyme extract in diisopropyl ether ( 5 $\mathrm{ml}$ ) at room temperature. After stirring for 6 hours, the reaction was followed up (TLC) and the products were separated as described in the previous general procedure to obtain cyanohydrin $(R)-3$ or $(R, S)-21 \mathrm{~b}$ in yields of $82 \%$ and $67 \%$, respectively.

Determination of the enantiomeric excess through derivatization with naproxen chloride

Step 1: Preparation of naproxen chloride (S)-7: (29)

Naproxen ${ }^{\circledR}(S)-5$ (obtained from commercially available tablets after extraction with chloroform) $(0.03$ mole, $7 \mathrm{~g})$ was refluxed with freshly distilled oxalyl chloride $6(0.03$ mole, $3.8 \mathrm{~g}, 2.6 \mathrm{ml})$ in dry hexane for $2 \mathrm{hr}$ under dry argon atmosphere. The volatile materials were removed in vacuo to leave naproxen chloride as a pale yellow residue.

Step 2: Addition of naproxen chloride

A solution of naproxen chloride $(S)-7$ (from step 1), in $10 \mathrm{ml}$ of dry methylene chloride, was added dropwise to a mixture of the appropriate cyanohydrin ( 0.01 mole) and pyridine $(0.01$ mole, $0.8 \mathrm{~g}, 0.85 \mathrm{ml})$ in $10 \mathrm{ml}$ of dry methylene chloride with stirring at $0^{\circ} \mathrm{C}$ under dry argon atmosphere. The cooling bath was removed and the reaction mixture was stirred for further $3 \mathrm{hr}$ at room temperature. An additional volume of methylene chloride $(30 \mathrm{ml})$ was added, then the reaction mixture was washed with a saturated solution of sodium carbonate $(3 \times 20 \mathrm{ml})$, distilled water $(3 \times 20 \mathrm{ml})$ and dried over anhydrous sodium sulphate. The solid material was filtered off and the volatile materials were removed under reduced pressure. The solid product, so obtained, was collected and chromatographed on silica gel through eluting with petroleum ether $60-80{ }^{\circ} \mathrm{C} /$ acetone $(9: 1)$.

(2S)-((R)-4-Chlorophenyl)(cyano)methyl)-2-(6-methoxynaphthalen-2-yl) propanoate $(R, 2 S)-(8)$

de $95 \%,[\alpha]_{\mathrm{D} / 25}=-104$. Colourless crystals, m. p. $130-132{ }^{\circ} \mathrm{C}$, yield $60 \%$. IR [KBr, $\left.\mathrm{cm}^{-1}\right): 3059$ (C-H, aromatic); 2935 (C-H aliphatic, asymmetric); 2858 (C-H aliphatic, symmetric); $2238(\mathrm{C} \equiv \mathrm{N}) ; 1744(\mathrm{C}=\mathrm{O}$, ester $) ; 1624,1604(\mathrm{C}=\mathrm{C}$, aromatic) and $1247\left(\mathrm{C}-\mathrm{O}\right.$, ester). ${ }^{1} \mathrm{H}-\mathrm{NMR}$ (DMSO-d $\left.{ }_{6}, \delta \mathrm{ppm}\right): 1.48(3 \mathrm{H}, \mathrm{C}-$

Egypt. J. Chem. 53, No. 5 (2010) 
$\left.\mathrm{CH}_{3}, \mathrm{~d}, \mathrm{~J}_{\mathrm{HH}}=7.6 \mathrm{~Hz}\right) ; 3.83\left(3 \mathrm{H}, \mathrm{O}-\mathrm{CH}_{3}, \mathrm{~s}\right) ; 4.08\left(1 \mathrm{H}, \mathrm{CH}-\mathrm{CH}_{3}, \mathrm{q}, \mathrm{J}_{\mathrm{HH}}=7.6 \mathrm{~Hz}\right)$; $6.72(1 \mathrm{H}, \mathrm{O}-\mathrm{CH}, \mathrm{s}) ; 7.26-7.74$ ( 10H, aromatics, m). MS m/z (\%): $379(60 \%)$. Analyses calculated (\%) for $\mathrm{C}_{22} \mathrm{H}_{18} \mathrm{ClNO}_{3}$ (379.84): C, 69.57; H, 4.78; Cl, 9.33; $\mathrm{N}, 3.69$. Found (\%):C, 69.62; H, 4.77; Cl, 9.22; N, 3.60. C,69.57; H, 4.78; Cl, $9.33 \mathrm{~N}, 3.69$.

(2S)-(1-Cyanocyclohex-1-yl)-2-(6-methoxynaphthalen-2-yl)propanoate (2S)-22a

IR $\left(\mathrm{KBr}, \mathrm{cm}^{-1}\right): 3035(\mathrm{C}-\mathrm{H}$ aromatic); 2972 (C-H aliphatic, asymmetric); 2936 (C-H aliphatic, symmetric); 1737 (C=O, ester); 1628, 1603 (C=C, aromatic) and $1230\left(\mathrm{C}-\mathrm{O}\right.$, ester). ${ }^{1} \mathrm{H}$ NMR (DMSO-d ${ }_{6}, \delta$ ppm): 1.19-1.40 (6H, $\mathrm{Cc}, \mathrm{Cd}$ and Ce cyclohexyl protons, m); $1.47\left(3 \mathrm{H}, \mathrm{CH}-\mathrm{CH}_{3}, \mathrm{~d}, \mathrm{~J}_{\mathrm{HH}}=6.9 \mathrm{~Hz}\right) ; 1.80$ $\left(2 \mathrm{H}, \mathrm{Cb}\right.$ and $\mathrm{Cf}$ axial protons, $\left.\mathrm{dt}, \mathrm{J}_{\mathrm{HH}}=6.9 \mathrm{~Hz}, \mathrm{~J}_{\mathrm{HH}}=13.0 \mathrm{~Hz}\right) ; 2.02(2 \mathrm{H}, \mathrm{Cb}$ and $\mathrm{Cf}$ equatorial protons, dt, $\left.\mathrm{J}_{\mathrm{HH}}=6.9 \mathrm{~Hz}, \mathrm{~J}_{\mathrm{HH}}=13.0 \mathrm{~Hz}\right) ; 3.83\left(3 \mathrm{H}, \mathrm{O}-\mathrm{CH}_{3}, \mathrm{~s}\right) ; 3.99$ $\left(1 \mathrm{H}, \mathrm{CH}-\mathrm{CH}_{3}, \mathrm{q}, \mathrm{J}_{\mathrm{HH}}=6.9 \mathrm{~Hz}\right) ; 7.13\left(1 \mathrm{H}, \mathrm{Ck}-\mathrm{H}, \mathrm{d}, \mathrm{J}_{\mathrm{HH}}=9.2 \mathrm{~Hz}\right) ; 7.27(1 \mathrm{H}, \mathrm{Cm}-$ $H, \mathrm{~s}) ; 7.37\left(1 \mathrm{H}, \mathrm{Co}-H, \mathrm{~d}, \mathrm{~J}_{\mathrm{HH}}=8.4 \mathrm{~Hz}\right) ; 7.72(1 \mathrm{H}, \mathrm{Ci}-H, \mathrm{~s})$ and $7.78(2 \mathrm{H}, \mathrm{Cl}-\mathrm{H}$, Cp- $H, \mathrm{~m})$. MS m/z (\%): 337 (25\%). Analyses calculated (\%) for $\mathrm{C}_{21} \mathrm{H}_{23} \mathrm{NO}_{3}$ (337.42): C, 74.75; H, 6.87; N, 4.15. Found (\%):C, 74.79; H, 6.86; N, 4.14.

$(1 ` R, 2 S)(2 S)-((1 R, 1 S)-(1-C y a n o-2-m e t h y l c y c l o h e x-1-y l)-2-(6 m e t h o x y n a p h t h a l e n-2-$ $y l)$ - propanoate $(1 R, 2 S)(1 S, 2 S)-22 b$

Brown crystals, m. p. 72-74; yield 90\%. IR $\left(\mathrm{KBr}, \mathrm{cm}^{-1}\right): 3048(\mathrm{C}-\mathrm{H}$, aromatic); $2938(\mathrm{C}-\mathrm{H}$, aliphatic asymmetric); $2862(\mathrm{C}-\mathrm{H}$ aliphatic, symmetric); $2100(\mathrm{C} \equiv \mathrm{N})$; $1747(\mathrm{C}=\mathrm{O}$, ester); $1604(\mathrm{C}=\mathrm{C}$, aromatic); $1452(\mathrm{C}-\mathrm{H}$ aliphatic, asymmetric deformation); 1482 (C-H aliphatic, symmetric deformation); 1227 (C-O, ester); 1174 (C-O, aromatic); $1084\left(\mathrm{C}-\mathrm{O}\right.$, ester). ${ }^{1} \mathrm{H}$ NMR (DMSO-d $\left.6^{-} \delta \mathrm{ppm}\right): 0.67(3 \mathrm{H}$, $\left.\mathrm{Cb}-\mathrm{CH}_{3}, \mathrm{~d}, \mathrm{~J}_{\mathrm{HH}}=6.9 \mathrm{~Hz}\right) ; 1.18-1.53(6 \mathrm{H}, \mathrm{Cc}, \mathrm{Cd}, \mathrm{Ce}$ cyclohexyl protons, m); 1.48 $\left(3 \mathrm{H}, \mathrm{CH}-\mathrm{CH}_{3}, \mathrm{~d}, \mathrm{~J}_{\mathrm{HH}}=6.9 \mathrm{~Hz}\right) ; 1.69\left(1 \mathrm{H}\right.$, axial $\mathrm{Cf}-\mathrm{H}, \mathrm{dt}, \mathrm{J}_{\mathrm{HHgem}}=12.3 \mathrm{~Hz}, \mathrm{~J}_{\mathrm{HHvic}}=7.6$ $\mathrm{Hz}) ; 1.82(1 \mathrm{H}$, equatorial Cf- $H, \mathrm{~m}) ; 2.75(1 \mathrm{H}, \mathrm{Cb}-H$ of both isomers, $\mathrm{m}) ; 3.83(3 \mathrm{H}$, $\left.\mathrm{O}-\mathrm{CH}_{3}, \mathrm{~s}\right) ; 3.97\left(1 \mathrm{H}, \mathrm{CH}-\mathrm{CH}_{3}, \mathrm{q}, \mathrm{J}_{\mathrm{HH}}=6.9 \mathrm{~Hz}\right) ; 7.14\left(1 \mathrm{H}, \mathrm{Ck}-\mathrm{H}, \mathrm{dd}, \mathrm{J}_{\mathrm{HH}}=9.2 \mathrm{~Hz}\right.$, $\left.\mathrm{J}_{\mathrm{HH}}=3.1 \mathrm{~Hz}\right) ; 7.25(1 \mathrm{H}, \mathrm{Cm}-H, \mathrm{~s}) ; 7.36\left(1 \mathrm{H}, \mathrm{Co}-H, \mathrm{dd}, \mathrm{J}_{\mathrm{HH}}=8.4 \mathrm{~Hz}, \mathrm{~J}_{\mathrm{HH}}=1.5 \mathrm{~Hz}\right)$; $7.64(1 \mathrm{H}, \mathrm{Ci}-H, \mathrm{~s})$ and 7.78 ( $\left.2 \mathrm{H}, \mathrm{Cl}-\mathrm{H}, \mathrm{Cp}-\mathrm{H}, \mathrm{dd}, \mathrm{J}_{\mathrm{HH}}=8.4 \mathrm{~Hz}, \mathrm{~J}_{\mathrm{HH}}=2.4 \mathrm{~Hz}\right) . \mathrm{MS}$ $\mathrm{m} / \mathrm{z}(\%): 351(10 \%)$. Analyses calculated (\%) for $\mathrm{C}_{22} \mathrm{H}_{25} \mathrm{NO}_{3}$ (351.45): C, 75.19; H, 7.17; N, 3.99. Found (\%):C, 75.15; H, 7.17; N, 3.89.

(2S)-((1R )-1- Cyano-2 - methylcyclohex -1-yl)-2- (6-methoxynaphthalen-2-yl)propanoate $(1 R, 2 S)-22 b$

de $: 90 \% \cdot[\alpha]_{\mathrm{D} / 25}=+61$. Brown crystal, yield $80 \%$, m.p. $74-76{ }^{\circ} \mathrm{C}$. IR $(\mathrm{KBr}$, $\left.\mathrm{cm}^{-1}\right)$ : 3057 (C-H aromatic); $2936(\mathrm{C}-\mathrm{H}$ aliphatic, asymmetric); $2862(\mathrm{C}-\mathrm{H}$ aliphatic, symmetric); $2237(\mathrm{C} \equiv \mathrm{N}) ; 1744(\mathrm{C}=\mathrm{O}$ ester $) ; 1631,1606 \quad(\mathrm{C}=\mathrm{C}$ aromatic); 1455 (C-H deformation, asymmetric); 1387 (C-H deformation, symmetric); 1222 (C-O ester) and 1028 (C-O ether). ${ }^{1} \mathrm{H}$ NMR $\left(\mathrm{CDCl}_{3}, \delta \mathrm{ppm}\right)$ : $0.81\left(3 \mathrm{H}, \mathrm{Cb}-\mathrm{CH}_{3}, \mathrm{~d}, \mathrm{~J}_{\mathrm{HH}}=6.9 \mathrm{~Hz}\right) ; 1.21-1.65(6 \mathrm{H}, \mathrm{Cc}, \mathrm{Cd}, \mathrm{Ce}$ cyclohexyl protons, m); $1.56\left(3 \mathrm{H}, \mathrm{CH}-\mathrm{CH}_{3}, \mathrm{~d}, \mathrm{~J}_{\mathrm{HH}}=6.9 \mathrm{~Hz}\right) ; 1.81(1 \mathrm{H}$, axial $\mathrm{Cf}-H$, dt, $\left.\mathrm{J}_{\mathrm{HH}}=7.6 \mathrm{~Hz}, \mathrm{~J}_{\mathrm{HH}}=12.3 \mathrm{~Hz}\right) ; 2.12(1 \mathrm{H}$, equatorial Cf- $H, \mathrm{~m}) ; 2.75(1 \mathrm{H}, \mathrm{Cb}-H, \mathrm{~m})$; $3.84\left(1 \mathrm{H}, \mathrm{CH}-\mathrm{CH}_{3}, \mathrm{q}, \mathrm{J}_{\mathrm{HH}}=6.9 \mathrm{~Hz}\right) ; 3.91\left(3 \mathrm{H}, \mathrm{O}-\mathrm{CH}_{3}, \mathrm{~s}\right) ; 7.14(1 \mathrm{H}, \mathrm{Ck}-\mathrm{H}$, dd, 
$\left.\mathrm{J}_{\mathrm{HH}}=9.2 \mathrm{~Hz}, \mathrm{~J}_{\mathrm{HH}}=3.1 \mathrm{~Hz}\right) ; 7.25(1 \mathrm{H}, \mathrm{Cm}-H, \mathrm{~s}) ; 7.36\left(1 \mathrm{H}, \mathrm{Co}-H, \mathrm{dd}, \mathrm{J}_{\mathrm{HH}}=8.4 \mathrm{~Hz}\right.$, $\left.\mathrm{J}_{\mathrm{HH}}=1.5 \mathrm{~Hz}\right) ; 7.64(1 \mathrm{H}, \mathrm{Ci}-\mathrm{H}, \mathrm{s})$ and $7.78\left(2 \mathrm{H}, \mathrm{Cl}-\mathrm{H}, \mathrm{Cp}-H, \mathrm{dd}, \mathrm{J}_{\mathrm{HH}}=8.4 \mathrm{~Hz}\right.$, $\left.\mathrm{J}_{\mathrm{HH}}=2.4 \mathrm{~Hz}\right) .{ }^{13} \mathrm{C} \mathrm{NMR}\left(\mathrm{CDCl}_{3}\right)$ : $16.08(\mathrm{Cg}) ; 18.29\left(\mathrm{Cb}-\mathrm{CH}_{3}\right) ; 22.99(C \mathrm{e})$; $24.48(C \mathrm{~d}) ; 31.04(\mathrm{Cc}) ; 34.37(C \mathrm{f}) ; 40.09(\mathrm{Cb}) ; 45.85(\mathrm{Ch}) ; 55.39\left(\mathrm{O}-\mathrm{CH}_{3}\right)$; 78.21 (Ca); 105.69, 116.43, 119.17, 125.99, 126.09, 127.43, 129.36, $135.05(C \equiv \mathrm{N}$ and aromatic carbons); $157.78(C \mathrm{n})$ and $172.49(C=\mathrm{O}) . \mathrm{MS} \mathrm{m} / \mathrm{z}(\%): 351(10$ $\%)$. Analyses calculated (\%) for $\mathrm{C}_{22} \mathrm{H}_{25} \mathrm{NO}_{3}$ (351.45): C, 75.19; H, 7.17; N, 3.99. Found (\%):C, 75.16; H, 7.17; N, 3.91 .

2- Reaction of cyanhydrins $(R, S)-3$ and $(R)-3$ with benzoyl chloride (9) and stearoyl chloride (11)

A solution of the acid chloride 9 and/or 11 ( 0.02 mole) in $10 \mathrm{ml}$ of dry methylene chloride was added dropwise by a syringe to a mixture of the cyanohydrin $(0.01$ mole, $1.83 \mathrm{~g}$ ) and pyridine $(0.01$ mole, $0.85 \mathrm{ml})$ in $10 \mathrm{ml}$ dry methylene chloride with stirring at $0^{\circ} \mathrm{C}$ under dry argon atmosphere. The cooling bath was removed and the reaction mixture was stirred for further $5 \mathrm{hr}$ at room temperature. An additional volume of methylene chloride $(30 \mathrm{ml})$ was added, then the reaction mixture was washed with a saturated solution of sodium carbonate $(3 \times 20 \mathrm{ml})$, distilled water $(3 \times 20 \mathrm{ml})$ and dried over anhydrous sodium sulphate. The solid material was filtered off and the filtrate was evaporated under reduced pressure where the residual substance were crystallized from petroleum ether $60-80{ }^{\circ} \mathrm{C}$.

(R)-(+)-(4-chlorophenyl)cyanomethyl benzoate $(R)-(+)-10$

$[\alpha]_{\mathrm{D} / 25}=+102$. Colourless crystals, m. p. $50-52{ }^{\circ} \mathrm{C}$, yield $65 \%$. IR $\left(\mathrm{KBr}, \mathrm{cm}^{-1}\right): 3068(\mathrm{C}-\mathrm{H}$, aromatic); $2959(\mathrm{C}-\mathrm{H}$, aliphatic $) ; 2333(\mathrm{C} \equiv \mathrm{N}) ; 1719$ $\left(\mathrm{C}=\mathrm{O}\right.$, ester); $1258(\mathrm{C}-\mathrm{O}$, ester $)$ and $1088\left(\mathrm{C}-\mathrm{Cl}\right.$, aromatic). ${ }^{1} \mathrm{H} \mathrm{NMR}\left(\mathrm{CDCl}_{3}\right)$ : $6.44(1 \mathrm{H}, \mathrm{CH}$ methine, s); $7.45(2 \mathrm{H}$, aromatic protons ortho to the $\mathrm{Cl}$ atom, $\mathrm{AB}$ system, $\left.\mathrm{d}, \mathrm{J}_{\mathrm{HH}}=8.4 \mathrm{~Hz}\right) ; 7.47\left(2 \mathrm{H}\right.$, aromatic protons meta to carbonyl, $\mathrm{dt}, \mathrm{J}_{\mathrm{HH}}=7.6$ $\left.\mathrm{Hz}, \mathrm{J}_{\mathrm{HH}}=6.8 \mathrm{~Hz}\right) ; 7.52(2 \mathrm{H}$, aromatic protons meta to the $\mathrm{Cl}$ atom, d, AB system, $\left.\mathrm{J}_{\mathrm{HH}}=8.4 \mathrm{~Hz}\right) ; 7.62\left(1 \mathrm{H}\right.$, aromatic proton para to carbonyl, t, $\left.\mathrm{J}_{\mathrm{HH}}=7.6 \mathrm{~Hz}\right) ; 8.05$ $\left(2 \mathrm{H}\right.$, aromatic protons ortho to carbonyl, $\left.\mathrm{t}, \mathrm{J}_{\mathrm{HH}}=6.8 \mathrm{~Hz}\right) . \mathrm{MS} \mathrm{m} / \mathrm{z}(\%): 271(5 \%$, $\left.\mathrm{M}^{+}\right)$and $273\left(2 \%, \mathrm{M}^{+}+2\right)$. Analyses calculated (\%) for $\mathrm{C}_{15} \mathrm{H}_{10} \mathrm{ClNO}_{2}(271.70): \mathrm{C}$, 66.31; H, 3.71; Cl, 13.05; N, 5.16. Found (\%): C, 66.36; H, 3.65; Cl, 13.15; N, 5.03 .

$(R, S)$ - (4-chlorophenyl)(cyano)methyl stearate $(R, S)-12$

Colourless crystals , m.p. $=42-44{ }^{\circ} \mathrm{C}$, yield 70\%. IR $(\mathrm{KBr}, \mathrm{cm}-1): 2918(\mathrm{C}-$ $\mathrm{H}$ aliphatic, asymmetric); $2850(\mathrm{C}-\mathrm{H}$ aliphatic, symmetric); $1750(\mathrm{C}=\mathrm{O}$, ester); 1597 (C=C, aromatic); 1466 (C-H aliphatic, asymmetric deformation); 1379 (C$\mathrm{H}$ aliphatic, symmetric deformation); $1154(\mathrm{C}-\mathrm{O}$, ester) and $1096(\mathrm{C}-\mathrm{Cl}$, aromatic). ${ }^{1} \mathrm{H}$ NMR (DMSO-d $\left.{ }_{6}\right): 0.87\left(3 \mathrm{H}, \mathrm{CH}_{3}, \mathrm{t}, \mathrm{J}_{\mathrm{HH}}=6.1 \mathrm{~Hz}\right) ; 1.25(28 \mathrm{H}$, $\left.\left(\mathrm{CH}_{2}\right)_{13}, \mathrm{~m}\right) ; 1.63\left(2 \mathrm{H}, \mathrm{C}(\mathrm{O})-\mathrm{CH}_{2}-\mathrm{CH}_{2}, \mathrm{t}, \mathrm{J}_{\mathrm{HH}}=7.7 \mathrm{~Hz}\right) ; 2.39\left(2 \mathrm{H}, \mathrm{C}(\mathrm{O})-\mathrm{CH}_{2}, \mathrm{t}\right.$, $\left.\mathrm{J}_{\mathrm{HH}}=7.7 \mathrm{~Hz}\right) ; 6.39(1 \mathrm{H}, \mathrm{NC}-\mathrm{CH}, \mathrm{s}) ; 7.42(2 \mathrm{H}$, aromatic protons meta to the $\mathrm{Cl}$ atom, $\mathrm{d}, \mathrm{AB}$ system, $\left.\mathrm{J}_{\mathrm{HH}}=8.4 \mathrm{~Hz}\right)$ and $7.45(2 \mathrm{H}$, aromatic protons ortho to the $\mathrm{Cl}$ atom, d, AB system, $\left.\mathrm{J}_{\mathrm{HH}}=8.4 \mathrm{~Hz}\right)$. MS m/z (\%): $433(8 \%)\left[\mathrm{M}^{+}\right], 435(2 \%)$

Egypt. J. Chem. 53, No. 5 (2010) 
$\left[\mathrm{M}^{+}+2\right]$. Analyses calculated (\%) for $\mathrm{C}_{26} \mathrm{H}_{40} \mathrm{ClNO}_{2}$ (434.06): C, 71.95; H, 9.29; $\mathrm{Cl}, 8.17$; N, 3.23. Found (\%): C, 71.90; H, 9.34; Cl, 8.11; N, 3.19.

$(R)-(+)(4-$ chlorophenyl) (cyano)methyl stearate $(R)-(+)-12$

$[\alpha]_{\mathrm{D} / 25}=+162$. Colourless crystals, m.p. $42-44^{\circ} \mathrm{C}$, yield $75 \%$.

Reaction of cyanohydrins $(R, S)-3,(R)-3,(R, S)-15$ and $(R)-21 b$ with isocyanates 13 and 17

To a stirred mixture of the appropriate racemic and/or optically active cyanohydrin $(0.01 \mathrm{~mole})$ and triethylamine (10ul) in dry toluene $(10 \mathrm{ml})$ was added a solution of the appropriate isocyanate reagent $(0.012$ mole $)$ in toluene $(5 \mathrm{ml})$ at $0^{\circ} \mathrm{C}$ under an inert gas atmosphere. After stirring the reaction mixture for further $48 \mathrm{hr}$ at room temperature, the volatile materials were removed under reduced pressure where the residual substance was collected, washed with light petroleum, dried and recrystallized from petroleum ether $80-100{ }^{\circ} \mathrm{C}$.

(R,S)-(4-chlorophenyl)(cyano)methyl tert-butylcarbamate $(R, S)-14$

Colourless crystals, m. p. $80-82{ }^{\circ} \mathrm{C}$, yield $95 \%$.

(R)-(4-chlorophenyl)(cyano)methyl tert-butylcarbamate $(R)-(+)-14$

$[\alpha]_{\mathrm{D} / 25}=+55.8$. Colourless crystals, m.p. $80-82{ }^{\circ} \mathrm{C}$, yield $80 \%$. IR $\left(\mathrm{KBr}, \mathrm{cm}^{-1}\right)$ : $3345(\mathrm{~N}-\mathrm{H}) ; 3045$ (C-H aromatic); 2976 (C-H aliphatic, asymmetric); 2935 (C-H aliphatic, symmetric); $2043(\mathrm{C} \equiv \mathrm{N}) ; 1711 \quad(\mathrm{C}=\mathrm{O}$ ester $) ; 1598 \quad(\mathrm{C}=\mathrm{C}$ aromatic); 1455 (C-H deformation, asymmetric); 1391 (C-H deformation, symmetric); 1270 (C-O ester); $1069(\mathrm{CH}-\mathrm{O}) .{ }^{1} \mathrm{H}$ NMR $\left(\mathrm{CDCl}_{3}, \delta \mathrm{ppm}\right): 1.32$ $\left(9 \mathrm{H}, \mathrm{C}\left(\mathrm{CH}_{3}\right)_{3}, \mathrm{~s}\right) ; 4.77\left(1 \mathrm{H}, \mathrm{NH}, \mathrm{D}_{2} \mathrm{O}\right.$ exchangeable); $6.35(1 \mathrm{H}, \mathrm{NC}-\mathrm{CH}, \mathrm{s}) ; 7.40$ $\left(2 \mathrm{H}\right.$, aromatic protons meta to the $\mathrm{Cl}$ atom, $\mathrm{AB}$ system, $\mathrm{d}, \mathrm{J}_{\mathrm{HH}}=8.4 \mathrm{~Hz}$ ) and 7.44 $\left(2 \mathrm{H}\right.$, aromatic protons ortho to the $\mathrm{Cl}$ atom, $\mathrm{AB}$ system, $\left.\mathrm{d}, \mathrm{J}_{\mathrm{HH}}=8.4 \mathrm{~Hz}\right) .{ }^{13} \mathrm{C}$ NMR $\left(\mathrm{CDCl}_{3}\right)$ : $28.78\left(\left(\mathrm{CH}_{3}\right)_{3}\right) ; 51.39\left(\mathrm{C}-\left(\mathrm{CH}_{3}\right)_{3}\right) ; 62.31(\mathrm{CH}-\mathrm{O}) ; 116.55$ $(C \equiv \mathrm{N}) ; 129.12$ (2C, carbons ortho to the $\mathrm{Cl}$ atom); 129.50 (2C, carbons meta to the $\mathrm{Cl}$ atom); $131.19(C-\mathrm{C}-\mathrm{CN}) ; 136.36(C-\mathrm{Cl}) ; 151.83(C=\mathrm{O}) . \mathrm{MS} \mathrm{m} / \mathrm{z}(\%)$ : $266\left(\mathrm{M}^{+}, 8 \%\right) ; 268\left(\mathrm{M}^{+}+2,2 \%\right)$. Analysis calculated $(\%)$ for $\mathrm{C}_{13} \mathrm{H}_{15} \mathrm{ClN}_{2} \mathrm{O}_{2}$ (Yч7,Vr): C, 58.54; H, 5.67; Cl 13.29; N, 10.50. Found (\%): C, 58.49; H, 5.77; $\mathrm{Cl}, 13.20 ; \mathrm{N}, 10.39$.

\section{$(R, S)-($ phenyl)(cyano)methyl tert-butylcarbamate $(R, S)-16$}

Colourless crystals, m. p. $54{ }^{\circ} \mathrm{C}$, yield 95\%.IR $\left(\mathrm{KBr}, \mathrm{cm}^{-1}\right): 3361(\mathrm{~N}-\mathrm{H})$; 3032 (C-H aromatic); 2977 (C-H aliphatic, asymmetric); 2938 (C-H aliphatic, symmetric); $2215(\mathrm{C} \equiv \mathrm{N}) ; 1742(\mathrm{C}=\mathrm{O}$ ester $) ; 1527(\mathrm{C}=\mathrm{C}$, aromatic $) ; 1458(\mathrm{C}-\mathrm{H}$ deformation, asymmetric); 1396 (C-H deformation, symmetric); 1263 (C-O ester); 1073 (CH-O). ${ }^{1} \mathrm{H}$ NMR $\left(\mathrm{CDCl}_{3}\right): 1.29\left(9 \mathrm{H}, \mathrm{C}\left(\mathrm{CH}_{3}\right)_{3}, \mathrm{~s}\right) ; 4.75(1 \mathrm{H}, \mathrm{NH}, \mathrm{s}$, $\mathrm{D}_{2} \mathrm{O}$ exchangeable); $6.37(1 \mathrm{H}, \mathrm{NC}-\mathrm{CH}, \mathrm{s}) ; 7.43\left(1 \mathrm{H}\right.$, para proton, $\left.\mathrm{t}, \mathrm{J}_{\mathrm{HH}}=3.1 \mathrm{~Hz}\right)$; $7.44\left(2 \mathrm{H}\right.$, ortho protons, $\left.\mathrm{t}, \mathrm{J}_{\mathrm{HH}}=6.2 \mathrm{~Hz}\right) ; 7.50\left(2 \mathrm{H}\right.$, meta protons, $\mathrm{J}_{\mathrm{HH}}=6.2 \mathrm{~Hz}$, $\left.\mathrm{J}_{\mathrm{HH}}=3.1 \mathrm{~Hz}\right) . \mathrm{MS} \mathrm{m} / \mathrm{z}(\%): 232(10 \%)$. Analysis calculated $(\%)$ for $\mathrm{C}_{13} \mathrm{H}_{16} \mathrm{~N}_{2} \mathrm{O}_{2}$ (232.28): C, 67.22; H, 6.94; N, 12.06. Found (\%): C, 67.17; H, 7.04; N 12.09. 
$(5 R)$ - (3-(3,4-dichlorophenyl) -5-(4-chlorophenyl) -4- iminooxazolidin-2-one $(R)-(+)-19$

$[\alpha]_{\mathrm{D} / 25}=+129$. Yellowish crystal , m.p. $126-130{ }^{\circ} \mathrm{C}$, yield $65 \%$. IR $(\mathrm{KBr}$, $\left.\mathrm{cm}^{-1}\right): 3293(\mathrm{~N}-\mathrm{H}) ; 3095(\mathrm{C}-\mathrm{H}$, aromatic); $2924(\mathrm{C}-\mathrm{H}$, aliphatic); $1770(\mathrm{C}=\mathrm{O}$, lactone); $1683(\mathrm{C}=\mathrm{N}$, exocyclic); $1594(\mathrm{C}=\mathrm{C}$, aromatic) and 1130, 1090,1045 $\left(\mathrm{C}-\mathrm{Cl}\right.$, aromatic). ${ }^{1} \mathrm{H}$ NMR $\left(\mathrm{CDCl}_{3}\right): 5.83(1 \mathrm{H}, \mathrm{NC}-\mathrm{CH}, \mathrm{s}) ; 6.01(1 \mathrm{H}, \mathrm{NH}, \mathrm{bs})$; $7.35(1 \mathrm{H}, \mathrm{Cg}-H, \mathrm{~s}) ; 7.39\left(1 \mathrm{H}, \mathrm{Ce}-H, \mathrm{~d}, \mathrm{~J}_{\mathrm{HH}}=7.6 \mathrm{~Hz}\right) ; 7.42(2 \mathrm{H}, \mathrm{Ca}$ and $\mathrm{Cd}$ protons, $\left.\mathrm{d}, \mathrm{J}_{\mathrm{HH}}=7.6 \mathrm{~Hz}\right) ; 7.47\left(2 \mathrm{H}, \mathrm{Cb}\right.$ and Cc protons, $\left.\mathrm{d}, \mathrm{J}_{\mathrm{HH}}=7.6 \mathrm{~Hz}\right)$ and 7.60 $\left(1 \mathrm{H}, \mathrm{Cf}-H, \mathrm{~d}, \mathrm{~J}_{\mathrm{HH}}=7.6 \mathrm{~Hz}\right) . \mathrm{MS} \mathrm{m} / \mathrm{z}(\%): 354(8 \%)$. Analyses calculated for $\mathrm{C}_{15} \mathrm{H}_{9} \mathrm{Cl}_{3} \mathrm{~N}_{2} \mathrm{O}_{2}$ (355.61): C, 50.66; H, 2.55; Cl, 29.91; N, 7.88. Found (\%): C.50.71; H, 2.49; Cl 29,79; N, 7.77.

\section{(5R) -3-(3,4-dichlorophenyl ) -5-(2-methylcyclohex-1-yl) -4-iminooxazolidin-2-one}

$(R)-23$

Yellowish crystal, yield $54 \%$. IR $\left(\mathrm{KBr}, \mathrm{cm}^{-1}\right): 3422(\mathrm{~N}-\mathrm{H}) ; 3077(\mathrm{C}-\mathrm{H}$, aromatic); 2927 (C-H aliphatic, asymmetric); 2856 (C-H aliphatic, symmetric); $1727(\mathrm{C}=\mathrm{O}$, lactone); $1677(\mathrm{C}=\mathrm{N}$, exocyclic); $1590(\mathrm{C}=\mathrm{C}$, aromatic); $1471(\mathrm{C}-\mathrm{H}$ aliphatic, asymmetric deformation); 1377 (C-H aliphatic, symmetric deformation) and 1087, 1033 (C-Cl, aromatic). Its ${ }^{1} \mathrm{H}$ NMR spectrum (DMSO$\left.\mathrm{d}_{6}, \delta \mathrm{ppm}\right): 0.96\left(3 \mathrm{H}, \mathrm{Cb}-\mathrm{CH}_{3}, \mathrm{~d}, \mathrm{~J}_{\mathrm{HH}}=6.9 \mathrm{~Hz}\right) ; 1.21-2.21(8 \mathrm{H}$, cyclohexyl protons $\mathrm{c}-\mathrm{f}, \mathrm{m}), 2.49(\mathrm{Cb}-\mathrm{H}, \mathrm{m}) ; 6.09\left(1 \mathrm{H}, \mathrm{NH}, \mathrm{D}_{2} \mathrm{O}\right.$-exchange- able, bs) and $7.34(1 \mathrm{H}, \mathrm{Ci}-H, \mathrm{~s}) 7.40\left(1 \mathrm{H}, \mathrm{Ch}-H, \mathrm{~d}, \mathrm{~J}_{\mathrm{HH}}=7.6 \mathrm{~Hz}\right) ; 7.61\left(1 \mathrm{H}, \mathrm{Cg}-H, \mathrm{~d}, \mathrm{~J}_{\mathrm{HH}}=7.6\right.$ $\mathrm{Hz}$ ). Analyses calculated (\%) for $\mathrm{C}_{15} \mathrm{H}_{16} \mathrm{Cl}_{2} \mathrm{~N}_{2} \mathrm{O}_{2}$ (327.21): C, 55.06; $\mathrm{H} 4.93 ; \mathrm{Cl}$, 21.67; N, 8.56. Found (\%): 55.14; H, 4.88; Cl, 21.72, N, 8.49.

Acetylation of cyanohdrins $21 a,(R, S)-21 b$ and $(R)-21 b$ :

A solution of the cyanohydrin ( 0.02 mole), pyridine $(0.04$ mole, $3.2 \mathrm{ml})$ and acetic anhydride (24) $(0.04$ mole, $5 \mathrm{ml})$ in methylene chloride $(100 \mathrm{ml})$ was magnetically stirred for $12 \mathrm{hr}$ at room temperature. The organic layer was separated, washed with $5 \%$ sulphuric acid $(2 \times 25 \mathrm{ml})$, distilled water $(2 \times 25$ $\mathrm{ml})$, saturated sodium bicarbonate solution $(2 \times 25 \mathrm{ml})$ then dried over anhydrous sodium sulphate. Removal of the volatile materials under reduced pressure followed by chromatography on silica gel and eluting with petroleum ether 40$60 /$ acetone ${ }^{\circ} \mathrm{C}(98: 2)$ afforded the pure acetylated cyanohydrin.

1-Cyancyclohex-1-yl acetate (25a)

Colourless crystals, m. p. $44-46{ }^{\circ} \mathrm{C}$, yield $80 \%$. IR $\left(\mathrm{KBr}, \mathrm{cm}^{-1}\right): 2946(\mathrm{C}-\mathrm{H}$ aliphatic, asymmetric); 2865 (C-H aliphatic, symmetric); $2248(\mathrm{C} \equiv \mathrm{N}) ; 1752$ $(\mathrm{C}=\mathrm{O}$, ester); $1452(\mathrm{C}-\mathrm{H}$ aliphatic, asymmetric deformation); $1376(\mathrm{C}-\mathrm{H}$ aliphatic, symmetric deformation) and $1234\left(\mathrm{C}-\mathrm{O}\right.$, ester). ${ }^{1} \mathrm{H}\left(\right.$ DMSO- $\left._{6}\right): 1.28-$ $1.64(6 \mathrm{H}, \mathrm{Cc}-\mathrm{Ce}$ protons $) ; 1.83\left(2 \mathrm{H}, \mathrm{Cb}, \mathrm{Cf}\right.$ axial protons, $\mathrm{dt}, \mathrm{J}_{\mathrm{HHgem}}=12.2 \mathrm{~Hz}$, 
$\left.\mathrm{J}_{\mathrm{HHvic}}=9.9 \mathrm{~Hz}\right) ; 2.07\left(3 \mathrm{H}, \mathrm{CH}_{3}, \mathrm{~s}\right)$ and $2.14(2 \mathrm{H}, \mathrm{Cb}, \mathrm{Cf}$ equatorial protons, $\mathrm{dt}$, $\left.\mathrm{J}_{\mathrm{HHgem}}=13.7 \mathrm{~Hz}, \mathrm{~J}_{\mathrm{HHvic}}=7.7 \mathrm{~Hz}\right)$. MS m/z $(\%): 167\left(70 \%, \mathrm{M}^{+}\right)$. Analyses calculated (\%) for $\mathrm{C}_{9} \mathrm{H}_{13} \mathrm{NO}_{2}$ (167.21): C, 64.65; H, 7.84; N, 8.38. Found (\%):C, $64.71 ; \mathrm{H}, 7.78 ; \mathrm{N}, 8.31$.

$(R, S)-(2-m e t h y l c y c l o h e x-1-y l)($ cyano $)$ methyl acetate $(R, S)-25 b$

Colourless crystals, Yield: $85 \%$; m. p. $54{ }^{\circ} \mathrm{C}$. IR $\left(\mathrm{KBr}, \mathrm{cm}^{-1}\right): 2942(\mathrm{C}-\mathrm{H}$ aliphatic, asymmetric); $2871(\mathrm{C}-\mathrm{H}$ aliphatic, symmetric); $2243(\mathrm{C} \equiv \mathrm{N}) ; 1748$ $(\mathrm{C}=\mathrm{O}$ ester); 1456 (C-H aliphatic, asymmetric deformation); 1373 (C-H aliphatic, symmetric deformation); 1219 (C-O, ester); 1032 (NCC-O). ${ }^{1} \mathrm{H}$ NMR $\left(\mathrm{DMSO}_{6}, \delta \mathrm{ppm}\right): 1.00\left(3 \mathrm{H}, \mathrm{Cb}-\mathrm{CH}_{3}, \mathrm{~d}, \mathrm{~J}_{\mathrm{HH}}=6.5 \mathrm{~Hz}\right) ; 1.22-1.59(6 \mathrm{H}, \mathrm{Cc}-\mathrm{Ce}$ cyclohexyl protons, $\mathrm{m}) ; 1.73\left(1 \mathrm{H}, \mathrm{Cf}\right.$ axial proton, $\left.\mathrm{dt}, \mathrm{J}_{\mathrm{HH}}=10.0 \mathrm{~Hz}, \mathrm{~J}_{\mathrm{HH}}=7.6 \mathrm{~Hz}\right)$; $1.91(1 \mathrm{H}, \mathrm{Cf}$ equatorial proton, $\mathrm{m}) ; 2.06\left(3 \mathrm{H}, \mathrm{O}=\mathrm{C}-\mathrm{CH}_{3}, \mathrm{~s}\right) ; 2.51(1 \mathrm{H}, \mathrm{Cb}-\mathrm{H}, \mathrm{m})$. MS m/z (\%): $181(3 \%)$. Analysis calculated (\%) for $\mathrm{C}_{10} \mathrm{H}_{15} \mathrm{NO}_{2}$ (181.23): C, 66.27; H, 8.34; N, 7.73. Found (\%): C, 66.20; H, 8.38; N, 7.69.

$(R)-(+)-(2-m e t h y l c y c l o h e x-1-y l)($ cyano $)$ methyl acetate $(R)-(+)-25 b$

$[\alpha]_{\mathrm{D} / 25}=+87$, Yield: $80 \%$; m. p. $54{ }^{\circ} \mathrm{C}$.

Preparation of the corresponding $\alpha$-hydroxycarboxylic acids from cyanohydrins $(R)-3,(R, S)-3,21 a,(R, S)-21 b$ and $(R)-21 b$

General procedure

A solution of the appropriate cyanohydrin $(0.03$ mole $)$ in concentrated hydrochloric acid $(50 \mathrm{ml})$ was stirred for $16 \mathrm{hr}$ at room temperature, then refluxed for $5 \mathrm{hr}$. The reaction mixture was poured onto distilled water, then extracted with methylene chloride $(3 \times 25 \mathrm{ml})$. The combined organic extracts were dried over anhydrous sodium sulphate, filtered and evaporated in vacuo to yield the respective $\alpha$-hydroxycarboxylic acid.

(R,S)-1-(4-chlorophenyl)-1-hydroxyacetic acid $(R, S)-20$

Colourless crystals, m. p. $114-116^{\circ} \mathrm{C}$, yield $95 \%$.

(R)-(-)-1-(4-chlorophenyl)-1-hydroxyacetic acid (R)-(-)-

$[\alpha]_{\mathrm{D} / 25}=-75.4$. Colourless crystals, m. p. $114-116{ }^{\circ} \mathrm{C}$, yield $90 \%$. IR $\left(\mathrm{KBr}, \mathrm{cm}^{-1}\right): 3374(\mathrm{O}-\mathrm{H}) ; 3185(\mathrm{C}-\mathrm{H}, \quad$ aromatic $) ; 2924(\mathrm{C}-\mathrm{H}$ aliphatic, asymmetric); 2852 (C-H aliphatic, symmetric); 1671 (C=O, acid); 1591 $(\mathrm{C}=\mathrm{C}$, aromatic); $1284(\mathrm{C}-\mathrm{O}$ acid $) ; 1100(\mathrm{C}-\mathrm{O}$ alcohol) and $1069(\mathrm{C}-\mathrm{Cl}$, aromatic). ${ }^{1} \mathrm{H}$ NMR (DMSO-d $\left.\mathrm{d}_{6}\right): 4.82\left(1 \mathrm{H}, \mathrm{CH}\right.$ methine, $\left.\mathrm{d}, \mathrm{J}_{\mathrm{HH}}=3.8 \mathrm{~Hz}\right) ; 6.10$ $\left(1 \mathrm{H}, \mathrm{OH}, \mathrm{d}, \mathrm{D}_{2} \mathrm{O}\right.$-exchangeable, $\left.\mathrm{d}, \mathrm{J}_{\mathrm{HH}}=3.8 \mathrm{~Hz}\right) ; 7.35(2 \mathrm{H}, \mathrm{CH}$ meta to the $\mathrm{Cl}$ atom, $\mathrm{AB}$ system, $\left.\mathrm{J}_{\mathrm{HH}}=8.4 \mathrm{~Hz}\right) ; 7.40(2 \mathrm{H}, \mathrm{CH}$ ortho to the $\mathrm{Cl}$ atom, d, $\left.\mathrm{J}_{\mathrm{HH}}=8.4 \mathrm{~Hz}\right)$ and $7.42\left(1 \mathrm{H}, \mathrm{OH}\right.$ acid, $\mathrm{D}_{2} \mathrm{O}$ exchangeable $)$. MS m/z (\%): 186 $\left(\mathrm{M}^{+}, 3 \%\right)$ and $188\left(\mathrm{M}^{+}+2,<1 \%\right)$. Analyses calculated $(\%)$ for $\mathrm{C}_{9} \mathrm{H}_{9} \mathrm{ClO}_{3}$ (200.62): C, 53.88; H, 4.52; Cl, 17.67. Found (\%):C, 53.93; H, 4.47; Cl, 17.60 . 
1-hydroxycyclohexanecarboxylic acid (26a)

Colourless crystals, m.p. $116-118{ }^{\circ} \mathrm{C}$, yield $80 \%$. IR $\left(\mathrm{KBr}, \mathrm{cm}^{-1}\right): 3403$ (free O-H); 3282 (hydrogen bonded O-H); 2941 (C-H aliphatic, asymmetric); 2855 (C-H aliphatic, symmetric); 1682 (C=O, acid); 1447 (C-H aliphatic, asymmetric deformation); 1395 (C-H aliphatic, symmetric deformation); 1160 (C-O acid) and $\left.994\left(\mathrm{C}-\mathrm{O} \text { alcohol). }{ }^{1} \mathrm{H} \text { NMR (DMSO-d }\right)_{6}\right) 1.08-1.39$ (6H, Cc-Ce protons, $\mathrm{m}) ; 1.50\left(2 \mathrm{H}, \mathrm{Cb}, \mathrm{Cf}\right.$ axial protons, dt, $\left.\mathrm{J}_{\mathrm{HH} v i c}=6.9 \mathrm{~Hz}, \mathrm{~J}_{\mathrm{HH} g e m}=12.3 \mathrm{~Hz}\right) ; 1.57(2 \mathrm{H}$, $\mathrm{Cb}, \mathrm{Cf}$ equatorial protons, $\left.\mathrm{dt}, \mathrm{J}_{\mathrm{HH} v i c}=6.9 \mathrm{~Hz}, \mathrm{~J}_{\mathrm{HH} \text { gem }}=12.3 \mathrm{~Hz}\right) ; 6.93$ and $7.07(2 \mathrm{H}$, $\mathrm{D}_{2} \mathrm{O}$ exchangeable protons of hydroxyl and carboxyl groups). $\mathrm{MS} \mathrm{m} / \mathrm{z}(\%): 144$ $(35 \%)$. Analyses calculated (\%) for $\mathrm{C}_{7} \mathrm{H}_{12} \mathrm{O}_{3}$ (144.17): C, 58.32; H, 8.39. Found (\%): 58.37; H, 8.31.

(R,S)-1-hydroxy-2-methylcyclohexanecarboxylic acid $(R, S)-26 b$

Colourless crystals, yield $95 \%$, m. p. $98-100^{\circ} \mathrm{C}$.

(R)-(+)-1-hydroxy-2-methylcyclohexanecarboxylic acid $(R)-(+)-26 b$

$[\alpha]_{\mathrm{D} / 25}=+26$. Colourless crystals, m. p. $98-100{ }^{\circ} \mathrm{C}$, yield $90 \%$. IR $\left(\mathrm{KBr}, \mathrm{cm}^{-1}\right)$ : 3458 (O-H, acid); 3340 (O-H, alcohol); 2949 (C-H aliphatic, asymmetric); 2884 (C-H aliphatic, symmetric); 1705 ( $\mathrm{C}=\mathrm{O}$ acid); 1452 (C-H aliphatic, asymmetric deformation); $1350(\mathrm{C}-\mathrm{H}$, symmetric deformation); 1248 (C-O, acid) and $\left.1082\left(\mathrm{C}-\mathrm{O} \text {, alcohol). }{ }^{1} \mathrm{H} \text { NMR (DMSO-d }\right)_{6}\right): 0.77\left(3 \mathrm{H}, \mathrm{CH}_{3}, \mathrm{~d}, \mathrm{~J}_{\mathrm{HH}}=6.9\right.$ $\mathrm{Hz}) ; 0.89-1.67(6 \mathrm{H}, \mathrm{Cc}-\mathrm{Ce}$ protons, $\mathrm{m}) ; 1.77(1 \mathrm{H}, \mathrm{Cf}$ axial proton, dt, $\left.\mathrm{J}_{\mathrm{HHgem}}=10.7 \mathrm{~Hz}, \mathrm{~J}_{\mathrm{HHvic}}=4.6 \mathrm{~Hz}\right) ; 1.89\left(1 \mathrm{H}, \mathrm{Cf}\right.$ equatorial proton, $\mathrm{dt}, \mathrm{J}_{\mathrm{HH}}=10.7 \mathrm{~Hz}$, $\left.\mathrm{J}_{\mathrm{HH}}=3.8 \mathrm{~Hz}\right), 2.01(1 \mathrm{H}, \mathrm{Cb}-\mathrm{H}, \mathrm{m})$ and 6.25 and $6.80\left(\mathrm{D}_{2} \mathrm{O}\right.$ exchangeable protons). MS m/z (\%): $158(20 \%)$. Analyses calculated (\%) for $\mathrm{C}_{8} \mathrm{H}_{14} \mathrm{O}_{3}$ (158.20): C, 60.74; H, 8.92. Found (\%): C, 60.81; H, 8.88.

\section{References}

1. Effenberger, F ., Angew . Chem . Int. Ed . Engl . 33, 1555 (1994).

2. Effenberger, F. Chimia 53, 3 (1999).

3. Gregory, R.G.H ., Chem. Revs. 99, 3649 (1999).

4. Burkard, U. and Effenberger, F., Chem .Ber. 119, 1594 (1986).

5. Gröger, H., Adv. Synth. Catal. 343, 547 (2001).

6. Yosef, H.A.A., Morsy , N.M., Mahran, M.R.H. and Aboul- Enein , H.Y., J. Iran. Chem . Soc. 4(1), 46-58 ( 2007 )

7. Duffield, J. J. and Regan, A.C., Tetrahedron: Asymm .7, 663 (1996)

8. Effenberger, F. and Syed, J., Tetrahedron : Asymm. 9, 817 (1998).

Egypt. J. Chem. 53, No. 5 (2010) 
9. Syed, J., Förster, S. and Effenberger, F., Tetrhedron : Asymm .9, 905 (1998).

10. Effenberger, F., Hersch, B., Weingart, F., Ziegler, T. and Kühner, S., Tetrahedron Lett. 32, 2605 (1991).

11. Griengle, H., Klempier, N., Pchlauer, P., Schmidt, M., Shi, N. and Zabelinskaja Mackova, A.A. Tetrahdron, 54, 14477 (1998).

12. Effenberger, F., Roos, J., Kobler, C. and Bühler, H., Can . J. Chem. 80, 671 (2002).

13. Hunig, S. and Schüfer, M., Chem. Ber. 126, 177 (1993).

14. Crey, E. J . and Wang, Z., Terahdron Lett. 34, 4001 (1993).

15. Kogut, E. F., Thoen, J. C. and Lipoton, M. A., J. Org. Chem. 63, 4604 ( 1998).

16. North, M., Synlett. 807 ( 1993) .

17. Yaozhong, J., Xiangge, Z., Wenhao, H., Lanjun, W. and Aiqiao, M., Tetrahedron: Asymm. 6, 405 (1995).

18. Garcia Ruano, J. L., Martin Castro, A. M . and Rodriguez, J. H., Tetrahedron Lett. 32, 3195 (1991).

19. Yamamoto, Y., Nunokawa, K. Okamoto, K . Ohno, M . and Eguchi, S., Synthesis, $571(1995)$.

20. Lin, G. Han, S. and Li , Z., Tetrahedron, 55, 3531 (1999).

21. Ross, J. and Effenberger, F. Tetrahdron : Asymm. 10, 2817 (1999).

22. Chen, P., Han, S., Lin, G. and Li, Z., J. Org . Chem . 67, 8251 (2002).

23. Manuel Cruz Silva, M. Luisa Sáe Melo, M., Parolin, M., Tessaro, D., Riva, S. and Danieli, B. Tetrahedron : Asymm. 15, 21 (2004)..

24. Grger, H., Capan, E. Barthuler, A. and Vorlop, K.D., Org. Lett. 3, 1969 (2001)

25. Aboul-Enein, H.Y. and Abou Basha., L., Chirality and Drug Impact of Stereochemistry on Drug Development and Use, Chemical Analysis Series, Vol. 142. John Wiley \& Sons, Inc., pp.1-19 (1997)

26. Huuhtanen, T. T. and Kanerva, L.T. Tetrahedron : Asymm. 3, 1223 (1992)

27. Kanerva, L.T., Kilijunen, E. and Huuhtanen, T., Tetrahedron : Asymm. 4, 2355 (1993).

28. Smith, M.B., Organic Synthesis, International Edition $2^{\text {nd }}$ ed ., McGraw Hill Higher Education , pp . 11-32 (2000). 
29. Solis, A., Luna, H., Pereg, H.I., Manjarrez , N., Sanchez, R. and Gutierrez, A., Tetrahdron Lett. 39, 8759 ( 1998 ).

30. Eliel, E.L., Wilen, S.H. and Mander, L.N., Stereochemistry of Organic Compounds, John Wiley \& Sons Inc., New York, p. 322 (1994) .

31. Madhaven, O.V.B. and Martin, J.C., J. Org. Chem . 51, 1287 (1986) .

32. Greene, T.W., " Protective Groups in Organic Synthesis, New York, Wiley (1981).

33. Drozd, J., Chemical derivatization in gas chromatography. Journal of Chromatography Library, 19, Amesterdam, Elsevier.

34. Corson, B.B., Dodge, R.A., Harris, S.A. and Yeaw, J.S., Organic Synth. Coll. Vol. 1, 336 (1941).

35. Skehan, P., Storeng, R., Scudiero, D., Monks, A., McMahon, J., Vistica, D., Warren, J. T., Bokesch, H., Kenny, S. and Boyed, M.R., J. Natl. Cancer Inst. 82, 1107-1112 (1990).

36. The Merck Index, (An Encyclopedia of Chemicals, Drugs and Biologicals, $\left(13^{\text {th }} \mathrm{ed}\right.$.), Merck Research Laboratories, Division of Merck\& Co., Inc. Whitehouse Station, NJ (USA). No 4071 (p. 715) and No. 4080, 4081 (p. 7160) (2001).

37. Simpkins, H., Leslie, F.P. and Leslie, M.T., Cancer Res. 44, 613 (1984).

38. Kiljunen, E. and Kanerva, L.T., Tetrahedron: Asymm. 8, 1225 (1997).

39. Seely, M.K., Criddle, R.S. and Conn, E.E., J. Biol, Chem. 241, 4457-4462 (1966).

40. Altomare, A., Cascarano, G., Giacovazzo, C., Guagliardi, A., Burla, Polidori , G. and Camall, M., J. Appl. Cryst. 27, 435. (1994).

41. Macky, S., Gilmore, C.J., Edwards, C., Stewart, N. and Shankland, K., MaXus Computer Program for the Solution and Refinement of Crystal Structures, Brucker Nonius, The Netherlands; MacScience, Japan and The University of Glasgow, Glasgow, UK (1999).

42. Johnoson, C.K., ORTEP-II, A. Fortran Thermal-Ellipsoid Program, Report ORNL5138. Oak Ridge National Laboratory,Oak Ridge, Tennessee, USA (1976).

43. Zandberger, P., van der Linden, J., Brussee, J. and van der Gen, A., Synth. Commun., 21, 1387 (1991). 


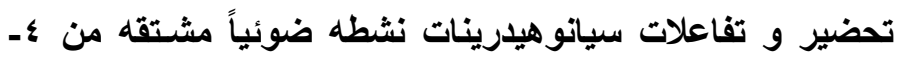

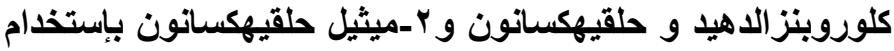
إنزيم (R)- هيدروكسى نيتريلاز المستخرج من نبات اللوز

هثام عبد الله عبد المنعم يوسف و أحمد مؤمن المصرى * و إيمان حامد إمام

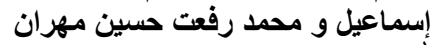

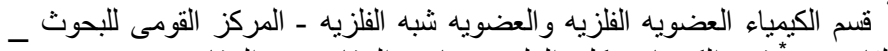

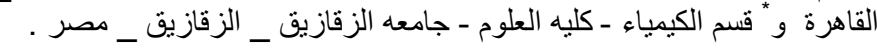

عند معالجه مركبات ع - كلوروبنز الدهيد (1) وحلقيهكسانون (2a) و و ك-ميثيل

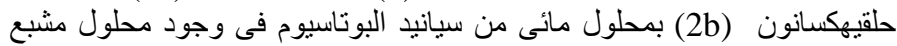

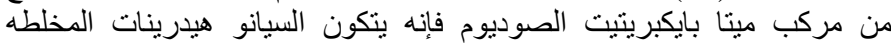

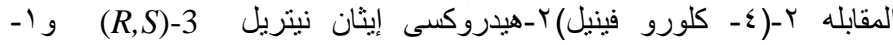

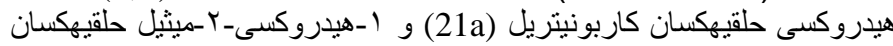
كاربونيتريل

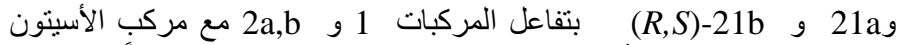

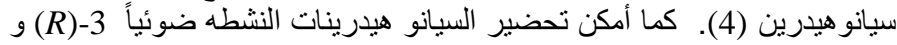
بمعالجه المركبين 1 و 2b)-21b

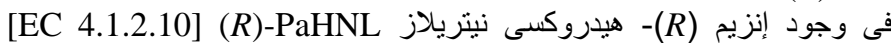

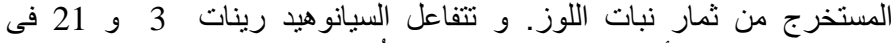

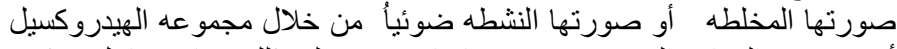

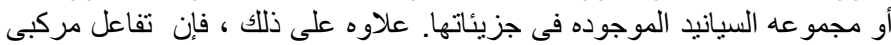

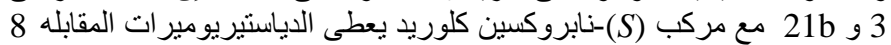

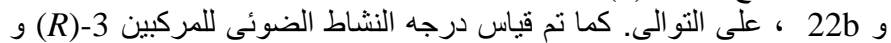

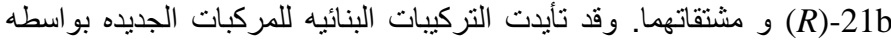

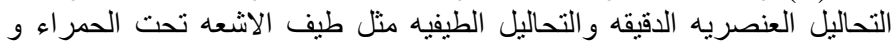

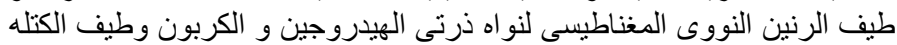

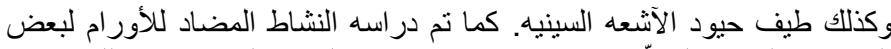

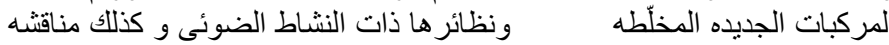
العلاقه بين التركيب الكيميائى و النشاط البيولوجى. 